\title{
Nanodiamenty: unikalne nanocząsteczki do zastosowania w biomedycynie i biotechnologii
}

\begin{abstract}
STRESZCZENIE
$\mathbf{N}$ anodiamenty to bardzo drobne cząstki diamentu, które ze względu na swój rozmiar w skali nano, unikalne właściwości fizykochemiczne oraz duży stosunek łatwo modyfikowalnej chemicznie powierzchni do objętości są interesujące dla biologów, chemików i fizyków. Praca ta stanowi przegląd literatury na temat ich przygotowania, właściwości i perspektyw związanych z możliwością ich zastosowania $\mathrm{w}$ naukach biomedycznych. Wysoka biokompatybilność nanodiamentów, potwierdzona przez szereg badań in vivo i in vitro, odróżnia je od innych nanocząstek i pozwala na ich zastosowanie jako neutralnego systemu transportu związków biologicznie czynnych. Takie nanocząstki można stosować jako nośniki peptydów, białek, kwasów nukleinowych, leków lub innych syntetycznych związków, które spowodują zamierzony efekt biologiczny w organizmie, $w$ bioobrazowaniu i inżynierii tkankowej. Obiecujące wyniki badań na różnych modelach biologicznych sugerują praktyczne zastosowania rozwiązań nanotechnologicznych opartych na nanodiamentach.
\end{abstract}

\section{WPROWADZENIE}

Nanotechnologia jest obecnie jedną z najbardziej dynamicznie rozwijających się nauk, obejmuje szereg technik związanych z badaniem struktur o rozmiarach nanometrycznych, a więc o wielkości pojedynczych atomów i ultradrobnych cząsteczek. Spośród wielu badanych nanocząsteczek na szczególną uwagę zasługują nanodiamenty (NDs, ang. nanodiamonds), co wynika z ich unikalnych właściwości fizyko-chemicznych odmiennych od ich odpowiedników w skali makro. NDs należą do rodziny nanocząsteczek węglowych, podobnie jak węglowe nanorurki, nanokulki, nanokropki, nanodruty oraz ich formy dendrytyczne $[1,2,18]$. Powszechnie klasyfikuje się je jako cząsteczki o oktaedralnej strukturze w zakresie wielkości od 2 do 10 nanometrów [3]. NDs mają zdolność tworzenia agregatów osiągających rozmiary rzędu setek nanometrów ze względu na obecność węgla $\mathrm{sp}^{2}$ w strukturze ich powierzchni [4]. Oktaedralny kształt oraz silne wiązania kowalencyjne pomiędzy atomami węgla $\mathrm{w}$ nanodiamentowej krystalograficznej sieci warunkują odporność mechaniczną, termiczną, chemiczną NDs, a także zapewniają bardzo korzystne właściwości magneto-optyczne tych nanocząsteczek [3]. Wielkość i struktura cząsteczki, na którą przekładają się właściwości fizyko-chemiczne NDs zależy od metody ich otrzymywania. Z kolei, właściwości fizyko-chemiczne mają decydujący wpływ na praktyczne zastosowanie NDs w biomedycynie i biotechnologii [5].

\section{OTRZYMYWANIE I OCZYSZCZANIE NANODIAMENTÓW}

Do niedawna NDs otrzymywano głównie trzema metodami stosując: (1) chemiczne osadzanie nanocząsteczek węgla z fazy gazowej (CVD, ang. chemical vapor deposition), (2) metodę wysokociśnieniowej i wysokotemperaturowej syntezy (HPHT, ang. high pressure, high temperature) w tłoczniach hydraulicznych oraz (3) metodę kontrolowanej detonacji materiałów wybuchowych i węgla w postaci mieszaniny o ujemnym bilansie tlenowym [3,6]. Ze względu na zainteresowanie możliwościami aplikacyjnymi NDs, opracowano szereg nowych metod umożliwiających ich szybkie i wydajne pozyskiwanie, wykorzystując w tym celu m.in. mikroplazmę [7], ablację laserową [8], wysokoenergetyczne mielenie kulowe mikrodiamentów [9], chlorowanie węglików [10], kawitację ultradźwiękową [11], czy wysokoenergetyczne napromieniowanie jonowe grafitu [12]. Strukturalna stabilność oraz możliwość modyfikacji nanocząsteczek determinowana jest w dużej mierze rodzajem atomów powierzchniowych [4]. NDs otrzymywane metodą detonacyjną charakteryzuje silnie zróżnicowana pod względem obecności grup funkcyjnych powierzchnia właściwa [13]. Obecność grup funkcyjnych zawierających tlen, takich jak: grupy aldehydowe, amidowe, eterowe, estrowe, hydroksylowe, karboksylowe, ketonowe, laktonowe, nitrowe oraz peroksydowe na powierzchni NDs (Ryc. 1) sprawia, że cząsteczki te mimo fizyko-chemicznej stabilności w szerokim zakresie środowisk, podatne są na różnego rodzaju che-

\section{mgr Patryk Nowicki ${ }^{\square}$,}

\section{dr hab. Elżbieta Czarniewska}

Zakład Fizjologii i Biologii Rozwoju Zwierząt, Instytut Biologii Eksperymentalnej, Wydział Biologii, Uniwersytet im. Adama Mickiewicza w Poznaniu

https://doi.org/10.18388/pb.2019_281

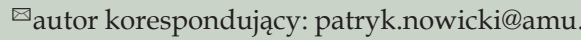
edu.pl

Słowa kluczowe: nanodiamenty, przenośniki, związki biologicznie aktywne, bioobrazowanie, terapia przeciwnowotworowa, inżynieria tkankowa

Wykaz skrótów: $\mathrm{ABC}$ - transporter z kasetą wiążącą ATP (ang. ATP-binding cassette); BMP - białko morfogenetyczne kości (ang. bone morphogenetic protein); CVD - chemiczne osadzanie nanocząsteczek węgla z fazy gazowej (ang. chemical vapor deposition); DOX - doksorubicyna (ang. doxorubicin); EGFR - receptor czynnika wzrostu naskórka (ang. epidermal growth factor receptor); EPI - epirubicyna (ang. epirubicin); Her2 - receptor ludzkiego naskórkowego czynnika wzrostu (ang. human epidermal growth factor receptor); HPHT - metoda wysokociśnieniowej i wysokotemperaturowej syntezy (ang. high pressure, high temperature), NDs - nanodiamenty (ang. nanodiamonds); PTX - paklitaksel (ang. paclitaxel); TGF- $\beta$ - transformujący czynnik wzrostu $\beta$ (ang. transforming growth factor $\beta$ ); VEGF - czynnik wzrostu śródbłonka naczyniowego (ang. vascular endothelial growth factor)

Podziękowanie: Niniejsza praca powstała podczas realizacji projektu o numerze 2017/27/N/NZ9/00266 wspieranego przez Narodowe Centrum Nauki. 


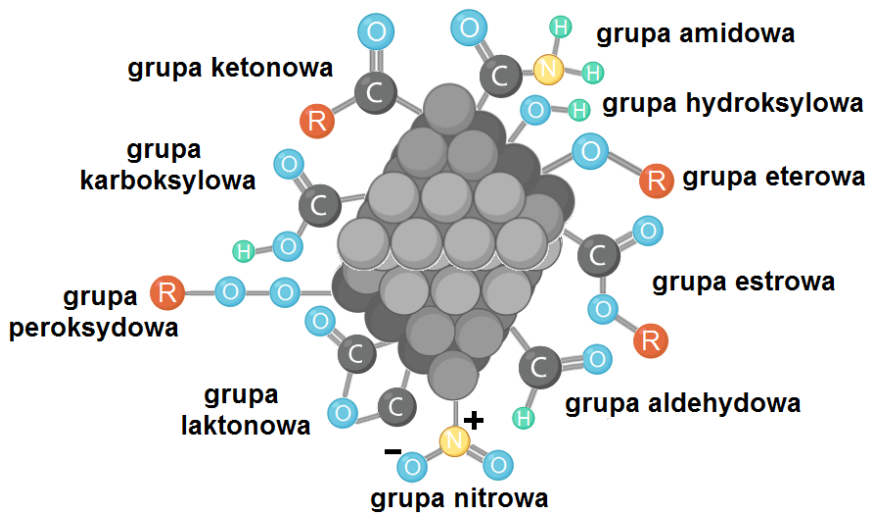

Rycina 1. Grupy funkcyjne zawierające tlen na powierzchni nanodiamentu ułatwiające jego funkcjonalizację.

miczne modyfikacje [5,14]. Właściwość ta w połączeniu z ich dużym stosunkiem powierzchni do objętości czyni NDs atrakcyjnym obiektem badań naukowych w zakresie nauk biomedycznych $[3,5]$.

Ze względu na perspektywę biomedycznego zastosowania NDs, muszą one cechować się niezwykle wysoką czystością [6]. Oczyszczanie przy użyciu różnego rodzaju metod jest więc kluczowym etapem pozyskiwania NDs [5,15] i ma największe znaczenie w przypadku NDs otrzymywanych drogą detonacji, ponieważ sadza detonacyjna zawiera NDs otoczone warstwą grafitu oraz częściowo utlenionym amorficznym węglem wraz z zanieczyszczeniami w postaci metali lub tlenków metali [16]. Niediamentowy grafitowy węgiel wraz z innymi niepożądanymi związkami może również znajdować się wewnątrz agregatów NDs [5,17]. Stopień i rodzaj zanieczyszczeń zależą od parametrów detonacji stosowanych podczas pozyskiwania NDs, takich jak: zapalnik, rodzaj metalu stanowiącego ścianę komory, domieszki w chłodziwach lub zanieczyszczenia odczynnika stosowanego w procesie detonacji [18]. Klasyczna metoda oczyszczania NDs polega na zastosowaniu silnych, ciekłych utleniaczy, takich jak: kwas siarkowy oraz jego mieszanina $\mathrm{z}$ bezwodnikiem chromowym lub kwasem azotowym, usuwającymi zanieczyszczenia NDs tlenkami metali [1,4]. Najbardziej skutecznym związkiem usuwającym zanieczyszczenia oraz rozbijającym agregaty NDs jest fluorowodór [16]. Mimo wysokiej skuteczności oczyszczania NDs za pomocą utleniaczy metoda ta jest kosztowna oraz niebezpieczna dla środowiska [17]. Z tego względu proponuje się zastosowanie alternatywnych metod, takich jak oczyszczanie NDs ozonem w podwyższonej temperaturze, czy wykorzystanie mikrofal $[1,7,19]$. W przypadku zanieczyszczeń NDs metalami zalecane jest również zastosowanie związków chelatujących np. kwasu wersenowego [20]. Ze względu na wysoką odporność termiczną NDs, proces oczyszczania wspomaga często wysoka temperatura, rzędu $420^{\circ} \mathrm{C}$ [16].

\section{MODYFIKACJA POWIERZCHNI I FUNKCJONALIZACJA NANODIAMENTÓW}

Modyfikacja powierzchni NDs wymaga rozbicia utworzonych agregatów NDs na pojedyncze nanocząsteczki [4]. W tym celu stosuje się mielenie kulowe, mielenie strumieniowe, obróbkę termiczną, sonikację lub frezowanie matry- cowe $[5,13,17,18,20,21]$. Etap rozbicia agregatów połączony jest najczęściej z frakcjonowaniem otrzymanego materiału poprzez jego dyspersję w odpowiednim separującym roztworze i wirowanie $\mathrm{w}$ gradiencie gęstości. Ta procedura pozwala na wyodrębnienie frakcji NDs o pożądanym zakresie wielkości $[17,18]$. Potwierdzenie powodzenia oczyszczania, rozbicia agregatów NDs oraz ich frakcjonowania według wielkości wymaga zastosowania dodatkowych technik np. spektroskopii ramanowskiej, fourierowskiej spektroskopii w podczerwieni, elektronowej mikroskopii skaningowej, rentgenowskiej mikroskopii fotoelektronów, wysokorozdzielczej mikroskopii transmisyjnej lub rentgenografii strukturalnej $[4,13,17,18]$. Techniki te pozwalają na precyzyjną charakterystykę struktury, wielkości oraz czystości otrzymanego materiału $[20,21]$.

Kluczowym etapem pozwalającym na wykorzystanie NDs w jakiejkolwiek dziedzinie biomedycyny jest funkcjonalizacja ich powierzchni $[3,4,5,14,17,18,20]$. Duża powierzchnia właściwa ND oraz obecność na jego powierzchni grup funkcyjnych zawierających tlen ułatwia proces funkcjonalizacji [1,2]. Zdolność NDs do łączenia się z różnego rodzaju grupami organicznymi umożliwia przyłączanie biomolekuł, takich jak: kwasy nukleinowe, peptydy lub białka oraz innych związków biologicznie aktywnych np. leków [3,14,17].

Jedną z najprostszych metod funkcjonalizacji jest niekowalencyjna funkcjonalizacja, w której przyłączane substancje oddziałują z powierzchnią NDs siłami elektrostatycznymi, hydrofobowymi lub Van der Waalsa $[1,17]$. W tym przypadku powierzchnia nanocząsteczki zostaje owinięta przez polipeptydy lub długołańcuchowe polimery [22]. Niekowalencyjna funkcjonalizacja NDs związkami powierzchniowo czynnymi, zawierającymi na swoich końcach grupy hydrofilowe obdarzone ładunkiem zwiększa właściwości dyspersyjne koniugatów w środowisku wodnym [23].

Zadaniem kowalencyjnej funkcjonalizacji jest trwałe przyłączenie cząsteczek do NDs za pośrednictwem obecnych na ich powierzchni grup funkcyjnych [17]. Dane literaturowe wskazują na szereg różnego rodzaju reakcji chemicznych umożliwiających przyłączanie określonych grup [23]. Jedną z metod pozwalających na uzyskanie hydroksylowanych NDs jest reakcja Fentona [24], w której zastosowanie mieszaniny siarczanu żelaza $\mathrm{z}$ nadtlenkiem wodoru przyczynia się nie tylko do wzbogacenia powierzchni NDs w grupy hydroksylowe, lecz także wspomaga usuwanie zanieczyszczeń w postaci innych niż diament odmian węgla, o czym świadczy wydzielanie dwutlenku węgla podczas reakcji [25]. Szerokie możliwości funkcjonalizacji powierzchni NDs stwarza również obecność grup karboksylowych. W tym przypadku atom węgla grupy karboksylowej związany jest z rdzeniem ND za pomocą jednego wiązania kowalencyjnego [26]. Modyfikacji tej można dokonać za pomocą różnego rodzaju reakcji chemicznych stosując utleniające kwasy mineralne np. kwas siarkowy, azotowy, nadchlorowy [17]. W wyniku łączenia grup karboksylowych z grupami aminowymi na powierzchni NDs w obecności odczynników aktywujących powstają amidy [20]. Obecność grup aminowych może również być wykorzystana do dalszej funkcjonalizacji NDs np. tetrametylorodaminą lub biotyną 
[27]. Wykazano silne wiązanie pomiędzy ujemnie naładowanymi karboksylanami na powierzchni NDs a dodatnio naładowanymi grupami aminowymi związków, takich jak: katalaza, mioglobina, lizozym, albumina surowicy bydlęcej, polilizyna i cytochrom C $[28,29,30]$. Funkcjonalizację NDs często poprzedza modyfikacja ich powierzchni polegająca na przyłączeniu grup estrowych [31]. Reakcję estryfikacji NDs zawierających grupę hydroksylową przeprowadza się z wykorzystaniem chlorków kwasów karboksylowych [32]. Z kolei traktowanie hydroksylowanych NDs chlorkami alkilowymi w obecności wodorku sodu prowadzi do otrzymania wiązania eterowego [33]. W przypadku obecności grupy karboksylowej na powierzchni NDs, wprowadzenia grupy estrowej można dokonać w reakcji z wodorotlenkami w środowisku kwaśnym [34].

Obecność licznych grup funkcyjnych na powierzchni NDs umożliwia wytworzenie koniugatów NDs ze związkami bardziej złożonymi np. z polimerami wykazującymi różnorodną aktywność chemiczną i biologiczną [3,17], np. biokompatybilnym i biodegradowalnym glikolem polietylenowym, polimerem kwasu mlekowego, kopolimerem kwasu glikolowego i mlekowego, czy polimetakrylanem metylu [35,36-39]. Powlekanie NDs polimerami o optymalnych właściwościach hydrofilowych i neutralnym lub ujemnym ładunku zwiększa stabilność koloidalną otrzymanych kompleksów oraz uzdatnia je do zastosowania w środowisku fizjologicznym [40].

\section{BIOKOMPATYBILNOŚĆ NANODIAMENTÓW}

Praktyczne wykorzystanie NDs w biomedycynie i biotechnologii wymusza konieczność zbadania stopnia cytotoksyczności tych nanocząsteczek. Przeprowadzono szereg badań in vitro oraz in vivo pozwalających na ocenę toksyczności NDs w stosunku do określonych komórek lub tkanek u różnych organizmów [3,14,15,17,18,20]. Wykazano, że NDs nie zaburzają aktywności oksydacyjnej mitochondriów ani syntezy ATP w komórkach nerwiaka zarodkowego [41]. Przeprowadzono także porównawcze badanie toksyczności nanomateriałów węglowych, takich jak: NDs, sadza węglowa, jednościenne oraz wielościenne nanorurki węglowe na komórkach nerwiaka zarodkowego oraz makrofagach i wykazano, że spośród przebadanych nanomateriałów najbardziej toksyczne były jednościenne nanorurki węglowe, nieco mniejszą toksyczność wykazywały nanorurki wielościenne, a następnie sadza węglowa, natomiast NDs były najmniej toksycznym nanomateriałem. Makrofagi eksponowane na NDs nie wydzielały reaktywnych form tlenu, natomiast po ekspozycji tych komórek na nanorurki wytwarzały one duże ilości tych wysoce reaktywnych cząsteczek [42]. W innym badaniu nie stwierdzono toksycznego oddziaływania NDs na fibroblasty płuc płodu ludzkiego oraz komórki epitelialne płuc, w przeciwieństwie do cytotoksycznie działających nanorurek [43]. Nie wykryto również cytotoksycznej aktywności oraz wpływu NDs na podziały i różnicowanie ludzkich komórek raka płuc [44]. Dowiedziono, że linia komórek nowotworowych HeLa pochłania NDs w o wiele większym stopniu niż wielościenne nanorurki czy tlenek grafenu, a toksyczność NDs w odróżnieniu od pozostałych nanostruktur jest minimalna [45]. Biokompatybilność NDs potwierdzono także wykazując brak zmian w ekspresji czynnika martwicy nowotworów oraz białek $\mathrm{z}$ rodziny $\mathrm{Bcl}-\mathrm{x}$ regulujących proces apoptozy, tym samym wykluczono możliwość indukcji stanu zapalnego oraz apoptozy przez NDs. W innym badaniu wykazano biozgodność z linią ludzkich komórek HT-29 gruczolakoraka jelita grubego [46]. Szereg eksperymentów wskazuje na konieczność stosowania $\mathrm{w}$ badaniach nad biokompatybilnością NDs o wysokim stopniu czystości i odpowiednio zmodyfikowanej powierzchni. Wykazano bowiem, że utlenione NDs powodowały uszkodzenia DNA embrionalnych komórek macierzystych w przeciwieństwie do NDs o niemodyfikowanej powierzchni [47], a karboksylowane NDs były toksyczne dla zarodków Xenopus [48]. W badaniach nad biokopatybilnością NDs w stosunku do erytrocytów udowodniono, że NDs mające na powierzchni grupę karboksylową tworzyły agregaty, które powodowały zmianę dyskocytów w echinocyty [49].

In vivo badano wpływ NDs na cały organizm modelowych bezkręgowców i kręgowców aplikując zwierzętom nanocząsteczki w różnej formie (np. w postaci zawiesiny lub hydrozolu) i różną drogą (np. doustną, dootrzewnową, dożylną, podskórną lub topikalną) [50-60]. Badania prowadzone przez nasz zespół wykazały, że NDs aplikowane drogą iniekcji do hemolimfy lub na powierzchnię kutikuli, nie powodowały apoptozy hemocytów chrząszcza Tenebrio molitor i były fagocytowane przez te komórki [50]. NDs nie wpływały również na liczbę hemocytów krążących w hemolimfie oraz nie zaburzały fagocytozy lateksowych kulek i procesu nodulacji (komórkowa odpowiedź immunologiczna) oraz aktywności oksydazy polifenolowej (humoralna odpowiedź immunologiczna) u wszystkich stadiów rozwojowych tego chrząszcza. Badanie biodystrybucji NDs w komórkach i tkankach T. molitor wykazało, że NDs gromadzone są głównie w cytoplazmie hemocytów. Wykryliśmy również obecność NDs w nielicznych komórkach ciała tłuszczowego, podczas gdy w komórkach cewek Malpighiego nie zaobserwowaliśmy ich występowania [50]. Z kolei wprowadzenie NDs do krwioobiegu myszy nie zaburzało odpowiedzi immunologicznej na infekcję bakteryjną oraz nie zaburzało zdolności makrofagów do fagocytozy [51]. Zbieżność uzyskanych wyników dla funkcjonalnie alternatywnych komórkowych modeli hemocytu i makrofaga, wskazuje na brak wpływu NDs na komórkową odporność u bezkręgowców i kręgowców [50,51]. Badania prowadzone na innym modelu owadzim, Acheta domesticus wskazują na uszkodzenia DNA hemocytów oraz komórek jelit, po aplikacji NDs drogą pokarmową [52]. Należy jednak podkreślić, że cytotoksyczny efekt stwierdzono po zastosowaniu znacznie większych dawek i długim czasie ekspozycji świerszcza na NDs niż miało to miejsce w przypadku chrząszcza T. molitor [50,52]. W badaniu toksyczności i dystrybucji NDs w układzie oddechowym myszy po podaniu intratrachealnym nie stwierdzono jakichkolwiek działań niepożądanych, na żadnym z jego odcinków, zarówno po 1, 7, 14, jak i 28 dniach od ekspozycji zwierzęcia na NDs. Ponadto wraz z upływem czasu zaobserwowano zmniejszenie ilości NDs w pęcherzykach płucnych, co było wynikiem fagocytozy NDs przez makrofagi migrujące przez tchawicę w stronę gardła [53]. Podobnie jak w przypadku owadów, wynik ten potwierdza kluczową rolę komórek mających zdolności fagocytarne w usuwaniu NDs. Z kolei intratrachealna aplikacja bardzo wysokich dawek NDs spowodowała toksyczne dzia- 
łanie NDs w płucach, wątrobie, nerkach oraz krwi myszy [54]. Toksyczność wysokich dawek NDs stwierdzono także u skorupiaków wodnych, z gatunku Daphnia magna, u których zaobserwowano akumulację nanocząsteczek w przewodzie pokarmowym, uniemożliwiającą prawidłowe trawienie [55]. Efektów toksycznych nie stwierdzono natomiast u myszy i szczurów po śródskórnej aplikacji NDs [56]. Dowiedziono również, że aplikacja NDs w formie hydrozolu drogą pokarmową nie powoduje zaburzeń wzrostu i rozwoju myszy, nie wpływa niekorzystnie na żaden organ wewnętrzny, a traktowane myszy wydają na świat zdrowe potomstwo [57]. Podobnie, żadnych efektów ubocznych nie zaobserwowano w przeciągu sześciu miesięcy od dożylnego wprowadzenia NDs szczurom oraz przedstawicielom rzędu naczelnych, z gatunku Macaca fascicularis [58]. Badania neurotoksyczności in vitro i in vivo u myszy na etapie rozwoju zarodkowego nie wykazały toksycznego działania NDs na komórki układu nerwowego [59]. Z kolei testy prowadzone na zarodkach danio pręgowanego wykazały dawko-zależny wpływ NDs na przeżywalność, wylęgalność, rytm pracy serca oraz aktywność lokomotoryczną, jednak zaobserwowane zmiany nie były istotne statystycznie [60]. Wyniki badań in vivo na bezkręgowcach i kręgowcach wskazują na konieczność określenia najwyższej bezpiecznej dawki, czasu ekspozycji i drogi aplikacji NDs oraz zastosowania odpowiedniej modyfikacji powierzchni NDs. Potwierdzenie braku efektów ubocznych $\mathrm{u}$ wyższych naczelnych, spokrewnionych filogenetycznie $\mathrm{z}$ człowiekiem, pozytywnie rokuje dla praktycznego zastosowania NDs w medycynie i biotechnologii.

\section{NANODIAMENTY JAKO NOŚNIKI ZWIĄZKÓW BIOLOGICZNIE AKTYWNYCH}

Badane są możliwości wykorzystania NDs jako nośników związków aktywnych biologicznie [3,5,14,17,18] (Ryc. 2). Obecny stan wiedzy wskazuje na szerokie możliwości niekowalencyjnej lub kowalencyjnej funkcjonalizacji aktywnymi biologicznie makromolekułami odpowiednio zmodyfikowanej chemicznie powierzchni NDs. Do tej pory do NDs przyłączono m.in. peptydy, białka, kwasy nukle- inowe oraz syntetycznie zaprojektowane leki o różnorodnej strukturze chemicznej [20,22-24,26-31].

Kluczową rolę w efektywności dostarczania związków do komórek ma interakcja kompleksu aktywnej cząsteczki i nanonośnika ze składnikami środowiska wewnętrznego organizmu [61]. Na początku kompleksy NDs i aktywnego biologicznie związku dyfundują przez błonę komórkową, a następnie docierają do docelowego miejsca wewnątrz komórki lub organelli [62]. Wewnątrzkomórkowy wychwyt kompleksów zależy od właściwości fizyko-chemicznych NDs oraz związków przyłączonych do ich powierzchni. W zależności od wielkości kompleksu oraz chemicznego charakteru biologicznie czynnej substancji, kompleks może być wprowadzony do wnętrza komórki drogą pinocytozy lub fagocytozy przy udziale różnego rodzaju białek np. klatryny [63]. Zbadano efektywność endocytozy NDs z wykorzystaniem linii ludzkich komórek raka płuc A549 oraz linii nierakowych: ludzkich komórek fibroblastów płuc HFL1 oraz ludzkich komórek nabłonka oskrzeli Beas-2b i udowodniono, że NDs wnikają drogą endocytozy za pośrednictwem klatryny do komórek nowotworowych w znacznie większym stopniu niż do komórek zdrowych [43,64,65].

W przeciwieństwie do konwencjonalnych leków, peptydy, białka oraz kwasy nukleinowe mają duży potencjał terapeutyczny ze względu na ich wysoką specyficzność oraz możliwość zastosowania znacznie niższych dawek terapeutycznych. Wykorzystanie makromolekuł jako terapeutyków jest jednak ograniczone ze względu na ich duże rozmiary, możliwość usuwania makromolekuł na drodze egzocytozy z komórek, krótki okres półtrwania in vivo, ich niestabilność strukturalną i słabą przenikalność przez błony biologiczne [66]. W celu przezwyciężenia tych trudności opracowano różnorodne systemy dostarczania leków, przy czym większość z nich opiera się na podejściu nanotechnologicznym $[3,5,14,17]$. Liczne badania wykazały możliwość wykorzystania powierzchni NDs umożliwiającej precyzyjny transport makromolekuł do wnętrza komórek [18,20,26,31].

\section{A) $8 \Rightarrow$ D) \\ Legenda: \\ 88 nanodiamenty

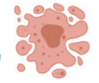 \\ komórki nowotworowe, $/$ kwasy nukleinowe, $2 / 8$ peptydy, \\ białka, $=1$ przeciwciała, \\ terapeutyki, Fe atomy żelaza}

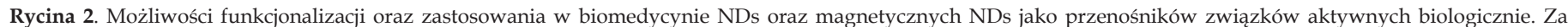

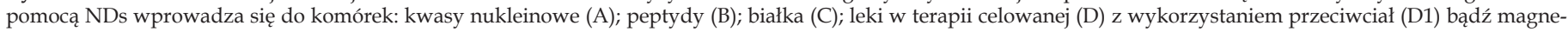
tycznych NDs (D2). 
Chemiczna budowa peptydów i białek, które na jednym końcu zawierają grupę aminową a na drugim karboksylową znacznie ułatwia ich wiązanie z NDs poprzez interakcję ładunków dodatnich i ujemnych. Fizyczną adsorpcję tych związków można uzyskać dzięki wykorzystaniu wiązań wodorowych [67] np. podczas opłaszczenia NDs insuliną bydlęcą skutkującą 80\% funkcjonalizacją powierzchni ND. $\mathrm{W}$ wyniku tej funkcjonalizacji zmiana jonizacji peptydu spowodowała dwudziestokrotne zwiększenie jego uwalniania w $\mathrm{pH} 10,5 \mathrm{w}$ porównaniu z $\mathrm{pH}$ obojętnym [68]. NDs wykorzystano również jako nośniki białek z rodziny BMP (ang. bone morphogenetic protein), które wspomagają morfogenezę kości. Zwiększenie miejscowego stężenia tych białek in vivo, poprzez opłaszczenie nimi NDs pozwoliło przezwyciężyć problem ich szybkiej dyfuzji, a tym samym polepszyć efekt terapeutyczny związany ze wzrostem proliferacji i różnicowania komórek kostnych [69]. W innym badaniu NDs były funkcjonalizowane transformującym czynnikiem wzrostu $\beta$ (TGF- $\beta$, ang. transforming growth factor $\beta$ ) w rozcieńczonym środowisku soli fizjologicznej. Utworzony w ten sposób koniugat charakteryzowała wysoka stabilność w środowisku wodnym, a uwalnianie aktywnej cytokiny stwierdzono $\mathrm{w}$ pożywkach zawierających surowicę [70]. Inne badanie, w którym do powierzchni NDs przyłączono królicze przeciwciało RAM, wykazało zwiększenie jego specyficzności do antygenu [71]. Powierzchnię NDs modyfikowano również za pomocą karboksymetylochitozanu, zwiększając tym samym pole powierzchni funkcjonalizacji oraz regulując uwalnianie leków z kompleksu w zależności od pH [72]. W podobny sposób wykorzystano NDs modyfikowane benzochinonem do ponownej funkcjonalizacji tego kompleksu za pomocą wiązania kowalencyjnego przeciwciałami IgG i stwierdzono stabilność utworzonego złożonego kompleksu w surowicy krwi [73].

Możliwości związane $\mathrm{z}$ wykorzystaniem NDs jako przenośników peptydów i białek nie ograniczają się jedynie do zastosowań terapeutycznych. Badania prowadzone przez nasz zespół dowiodły, że NDs można wykorzystać do transportu peptydów przez hydrofobowe anatomiczno-fizjologiczne bariery, takie jak kutikula owada. Sprzęgając NDs z Nebkolostatyną, 19-aminokwasowym peptydem o silnych immunoinhibicyjnych i gonadoinhibicyjnych właściwościach wykazaliśmy możliwość transkutikularnego przeniesienia tego peptydu z powierzchni kutikuli do hemocelu owada z zachowaniem jego biologicznej aktywności (Ryc. 3). W hemolimfie owada Neb-kolostatyna skompleksowana $\mathrm{z}$ nanodiamentami indukowała apoptozę hemocytów znacznie zmniejszając liczbę krążących hemocytów w hemolimfie oraz hamowała komórkową i humoralną odpowiedź immunologiczną u wszystkich stadiów rozwojowych T. molitor [50]. Efekt działania peptydu obserwowany po jego aplikacji w kompleksie z NDs na powierzchnię kutikuli był porównywalny do efektu uzyskanego po bezpośrednim wprowadzeniu peptydu do hemocelu za pomocą iniekcji. Sugerujemy, że możliwość pokonania hydrofobowego środowiska kutikuli przez Neb-kolostatynę skompleksowaną z NDs związana jest z czasową zmianą konformacji peptydu, wynikającą ze złączenia hydrofilowych łańcuchów bocznych Neb-kolostatyny z powierzchnią NDs. Funkcjonalizacja nanonośnika aktywnym, immunoinhibicyjnym i gonadoinhibicyjnym peptydem stanowi alternatywę dla wprowadzenia do ciała owada aktywnej cząsteczki drogą pokarmową. $W$ przyszłości to innowacyjne podejście do ograniczenia żywotności i rozrodu owadów może posłużyć

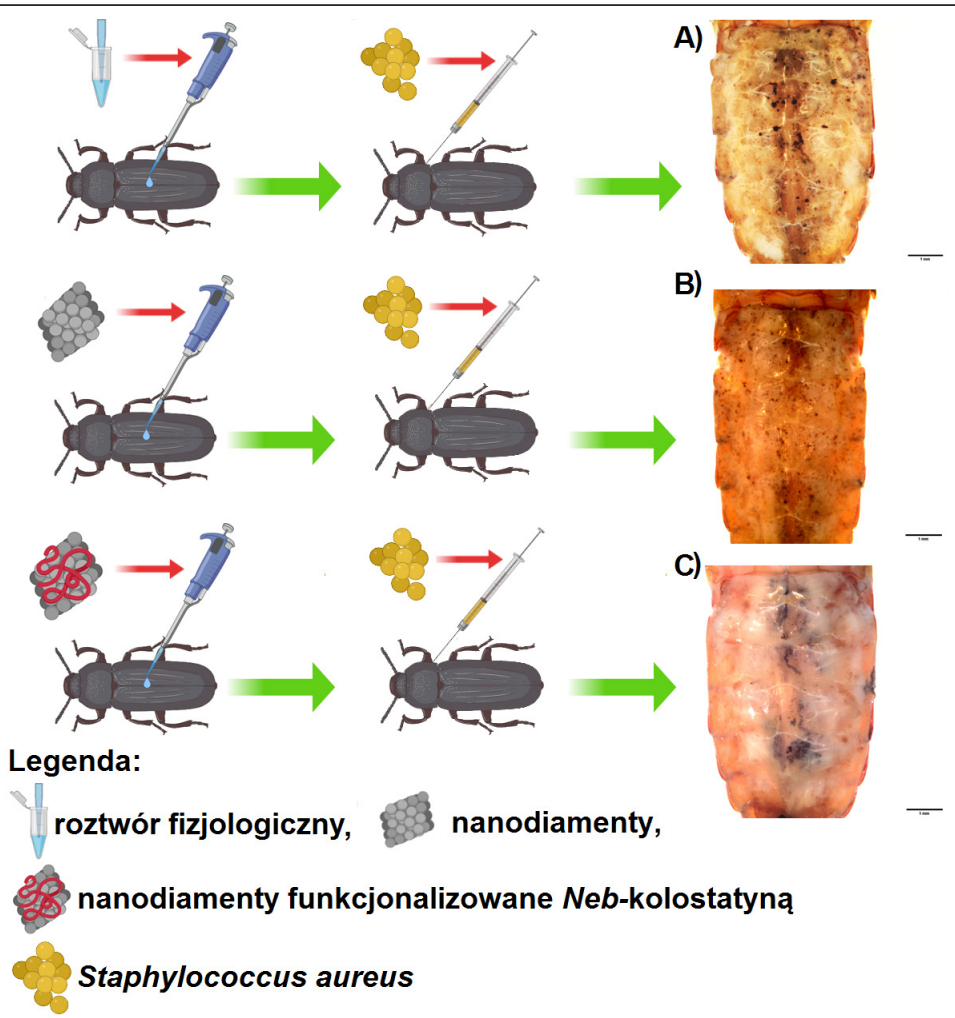

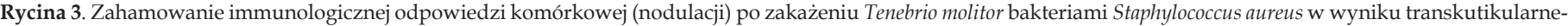

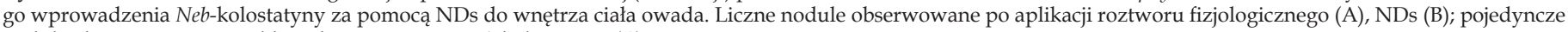
nodule obserwowane po aplikacji koniugatu ND-Neb-kolostatyna (C). 
do opracowania nowych metod zwalczania szkodników [50].

Podejście nanotechnologiczne stwarza również ogromne możliwości w terapii wielu chorób z wykorzystaniem kwasów nukleinowych np. DNA lub RNA, w tym mRNA, siRNA, miRNA, piRNA, snRNA, snoRNA [17]. Kwasy nukleinowe $\mathrm{w}$ bezpośredni sposób związane są nie tylko z regulacją ekspresji genów, lecz także wprowadzaniem modyfikacji potranslacyjnych, a wiele z nich wykazując właściwości katalityczne uczestniczy w reakcjach enzymatycznych, dzięki czemu terapia genowa stwarza możliwość kontroli nad produkcją białek i peptydów, które organizm wytwarza w nadmiarze lub niedomiarze, łącznie $\mathrm{z}$ białkami zaangażowanymi w proces apoptozy [74]. Dotychczas w celu wprowadzenia kwasów nukleinowych do komórek stosowano wirusowe wektory, takie jak adenowirusy lub retrowirusy, jednak ze względu na ograniczone rozmiary kapsydów, poszukiwano bardziej efektywnego przenośnika [75]. W tym celu wykorzystano NDs z powierzchnią zmodyfikowaną polietylenoiminą, które następnie koniugowano z plazmidowym DNA kodującym lucyferazę i następnie ten kompleks wprowadzano do komórek nowotworowych HeLa, uzyskując 70-krotne zwiększenie efektywności transfekcji [76]. NDs wykorzystano również jako dokomórkowy transporter siRNA w leczeniu mięsaka Ewinga. Wprowadzenie do komórek siRNA związanego z powierzchnią modyfikowanych wodorkiem polialliloaminy NDs, umożliwiło zahamowanie ekspresji genu EWS/FLI1 kodującego białko onkogenne zaangażowane w rozwój tego rzadkiego nowotworu [77]. W innym badaniu transport siRNA do wnętrza komórek przy udziale NDs modyfikowanych poliamidoaminą spowodował zahamowanie ekspresji onkoprotein E6 i E7 kluczowych w rozwoju raka szyjki macicy wywołanego wirusem HPV [78].

\section{WYKORZYSTANIE NANODIAMENTÓW W BIOOBRAZOWANIU}

Właściwości NDs umożliwiają ich szerokie zastosowanie nie tylko w oparciu o wykorzystanie potencjału nośnikowego, w leczeniu nowotworów lecz także na etapie określenia kluczowej dla dalszego postępowania terapeutycznego diagnozy [79].

Wiele badań potwierdziło możliwość wykorzystania nanocząsteczek, takich jak: metaliczne nanoklastry, nanosfery domieszkowane barwnikami, kropki kwantowe czy nanocząsteczki powlekane polimerami, jako fluorescencyjnych znaczników molekularnych do obrazowania komórkowego [80-84]. Zastosowanie tych nanostruktur niesie ze sobą jednak pewne ograniczenia związane m.in. z silnym rozpraszaniem światła w tkankach, blaknięciem kolorów, możliwością toksycznej degradacji sondy obrazującej lub autofluorescencją komórek $[85,86]$. Ze względu na korzystne właściwości magneto-optyczne uwarunkowane krystaliczną strukturą, NDs mogą być alternatywą dla wcześniej wymienionych nanocząsteczek [5]. Wysoki współczynnik załamania światła umożliwia uzyskanie ostrego piku w widmie spektroskopii fourierowskiej w podczerwieni oraz ramanowskiej spektroskopii [50,87]. Ramanowskie mapowanie wykorzystano w praktyce do lokalizacji NDs sprzę- żonych z hormonem wzrostu w celu określenia jego interakcji z receptorami błonowymi komórek raka płuc [88]. NDs w czystej postaci nie wykazują fluorescencji, stąd w celu wykorzystania ich do bioobrazowania należy wprowadzić modyfikacje niezbędne do jej uzyskania, takie jak koniugacja z fluorochromem lub utworzenie centrów barwnych [89]. Chemiczna koniugacja grupami aminowymi, ketonowymi, hydroksylowymi lub estrowymi w znaczący sposób wpływa na właściwości fluorescencyjne NDs [90]. Każdą funkcyjną grupe charakteryzuje emisja światła przy określonej długości fali, co daje możliwość obrazowania wielokolorowego [91]. Koniugując powierzchnię NDs z izocyjanianem oktadecylu i kwasem polikarboksymetylowym otrzymano kompleks, który po wniknięciu do komórek wykazywał jasną fluorescencję [92]. W innym badaniu wykazano, że NDs koniugowane $\mathrm{z}$ rozgałęzionymi łańcuchami poliglicerolu wykorzystać można do selektywnej detekcji integryn w komórkach HeLa oraz wewnątrzkomórkowej termodetekcji [93]. W naszych badaniach, w celu udowodnienia, że NDs mogą przenikać przez kutikulę owada dokonaliśmy modyfikacji NDs polegającej na oksydacji ich powierzchni, a następnie przyłączyliśmy fluorescencyjny barwnik, FITC. Dzięki fluorescencyjnemu wyznakowaniu NDs udowodniliśmy, że NDs przechodzą przez nanopory w kutikuli owada i wykazaliśmy ich dystrybucję w komórkach i tkankach T. molitor [50] (Ryc. 4A).

Alternatywnym sposobem bioobrazowania $\mathrm{z}$ użyciem NDs jest wykorzystanie ich centrów barwnych, czyli naturalnych bądź wprowadzonych sztucznie defektów krystalicznej struktury, posiadających zdolność do absorpcji i emisji światła w temperaturze pokojowej [79]. Ze względu na najczęściej występujące zanieczyszczenia NDs azotem, większość badań koncentruje się na wykorzystaniu nanocząsteczek, których centra barwne składają się z azotu i wakancji [94]. Centra te charakteryzują się silną absorpcją światła o długości fali $550 \mathrm{~nm}$ oraz stabilną emisją fluorescencji [95]. Ze względu na wysoki wskaźnik fotostabilności, pod uwagę brane jest również obrazowanie z użyciem NDs, których centra zawierają krzem lub lantanowiec, europ $[96,97]$. Sztuczne wytworzenie centrów barwnych uzyskuje się najczęściej poprzez napromieniowanie NDs wiązką wysokoenergetycznych elektronów, protonów, jonów helu lub promieni gamma, wykorzystując różnego rodzaju akceleratory [98]. Możliwość uzyskania silnego sygnału o długotrwałej stabilności, który można odróżnić od autofluorescencji komórek w połączeniu z biokompatybilnością NDs sprawia, że nanocząsteczki te odgrywają istotną rolę w diagnozowaniu chorób $[3,5,17,18,20]$. Oprócz korzystnych właściwości optycznych, NDs posiadają szereg innych cech fizyko-chemicznych umożliwiających ich wykorzystanie w biodetekcji, jako doskonałych czujników pola magnetycznego, elektrycznego, temperatury i ciśnienia $[99,100]$.

Rozwój nowych technologii w zakresie fotodetekcji NDs w połączeniu z rosnącymi możliwościami modyfikacji ich struktury krystalicznej, rzutującymi na właściwości optyczne stwarza wiele możliwości dla wykrywania tych nanocząsteczek nie tylko w komórce, ale także w poszczególnych jej organellach. Zastosowanie mikroskopii wymuszonego wygaszania emisji pozwoliło na odróżnienie fluorescencyjnych NDs opłaszczonych albuminą surowicy bydlęcej 


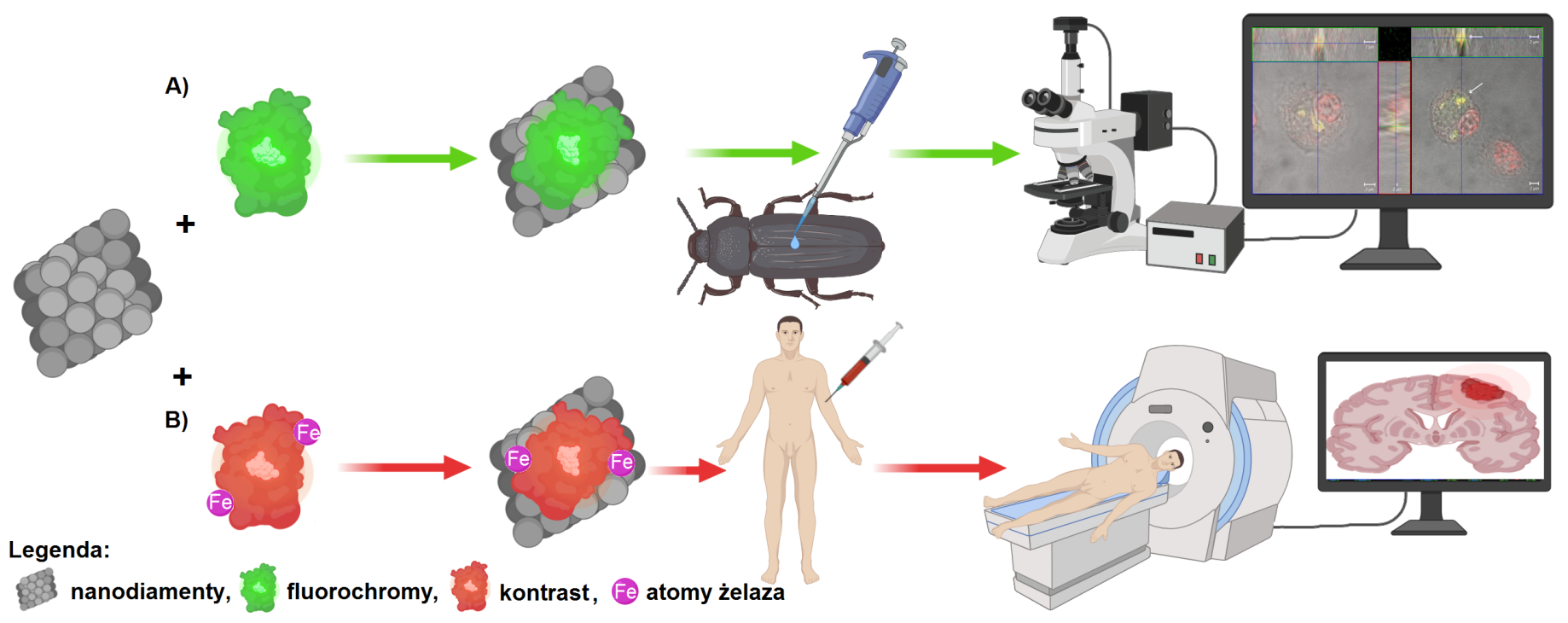

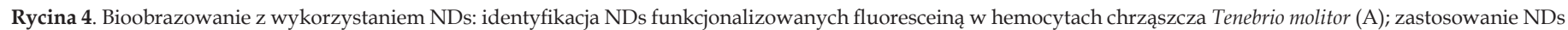
zawierających atomy żelaza w obrazowaniu narządów za pomocą rezonansu magnetycznego (B).

znajdujących się w cytozolu od NDs zlokalizowanych w endosomach [101]. Stefan Hell, nagrodzony Nagrodą Nobla w dziedzinie Chemii za udoskonalenie tej wysokorozdzielczej techniki mikroskopowej, zidentyfikował barwne centra NDs zawierające azot [102]. Centra te warunkują unikalny spin elektronowy oraz magnetycznie podatny stan podstawowy, co umożliwia ich ultraczułe i szybkie wykrywanie. Zmiana sygnału fluorescencyjnego $\mathrm{w}$ wyniku przejścia ze stanu podstawowego sugeruje możliwość obrazowania $\mathrm{z}$ wykorzystaniem rezonansu magnetycznego $\mathrm{w}$ nanoskali [103]. Defekty krystalicznej sieci uwarunkowane obecnością azotu sprawiają, że możliwa jest detekcja takich NDs $\mathrm{w}$ tkankach za pomocą rezonansu magnetycznego [104]. Metoda ta pozwoliła ponadto na wykazanie ruchu obrotowego fluorescencyjnych NDs w komórkach HeLa [105]. Wprowadzenie atomów żelaza do struktury krystalicznej NDs, nadaje im dodatkowe właściwości określane mianem superparamagnetyzmu. Tego rodzaju modyfikacja sprawia, że nanocząsteczki wykazują cechy magnetyczne po przyłożeniu zewnętrznego pola magnetycznego, które natychmiast tracą po usunięciu źródła pola [106]. Obecność domen magnetycznych nanoferromagnetyków lub nanoferrimagnetyków $\mathrm{z}$ powodzeniem może być wykorzystana $\mathrm{w}$ diagnostyce oraz terapii różnego rodzaju chorób [89]. NDs wzbogacone o atomy żelaza przebadane zostały pod kątem wykorzystania ich jako alternatywnego środka kontrastującego charakteryzującego się zmniejszoną cytotoksycznością w obrazowaniu za pomocą rezonansu magnetycznego [61] (Ryc. 4B). NDs o powierzchni zmodyfikowanej za pomocą jonów lub tlenków żelaza, opłaszczone dodatkowo związkami o działaniu antynowotworowym, mogą być doskonałym materiałem wzmacniającym efekty celowanej terapii antynowotworowej [107]. Przyłożenie zewnętrznego źródła pola magnetycznego do ciała pacjenta w miejscu lokalizacji nowotworu po wprowadzeniu do organizmu magnetycznych nanokoniugatów utrzymuje leczniczy kompleks w obszarze zmienionej nowotworowo tkanki, co może prowadzić do poprawy farmakokinetyki leków i umożliwia ochronę zdrowych tkanek przed niekorzystnym działaniem leków antynowotworowych, które skupiane są w bezpośrednim obrębie komórek rakowych [108]. Opłaszczone lakami, fluorescencyjne NDs można wykorzystać również do badania interakcji tych leków z komórkami oraz ich komponentami, określenia biodystrybucji leków, a także oceny zmian stężenia leków lub ich metabolitów w ustroju w czasie $[63,79,93,100,101]$. Badania interakcji NDs-transferyny i jej receptora z wykorzystaniem linii HeLa, pozwoliły uzyskać widma fluorescencyjne wykazujące brak wpływu interakcji białko-receptor na intensywność fluorescencji NDs [109]. Zjawisko fluorescencji NDs wykorzystano również w badaniach in vitro szybkości egzocytozy oraz wizualizacji podziałów multipotencjalnych komórek zrębowych raka szyjki macicy oraz preadipocytów [110]. Zaproponowano również wykorzystanie magnetycznych fluorescencyjnych NDs do wizualizacji komórek gruczolakoraka płuc, wykorzystując linię A549 oraz linię płodowych fibroblastów płucnych [111]. Wykorzystując zjawisko fluorescencji NDs wykazano powodzenie transfekcji komórek HeLa [112]. Obserwacje w czasie rzeczywistym wskazały na znikomy stopień egzocytozy NDs, co umożliwia długotrwałe śledzenie biomolekuł, którymi są opłaszczone i utrzymywanie ich przez długi czas wewnątrz komórki [110]. Podejście to zastosowane zostało przy wizualizacji wolno proliferujących nowotworowych komórek macierzystych, $\mathrm{z}$ wykorzystaniem linii komórek raka piersi AS-B145, a uzyskane wyniki sugerują możliwość zastosowania fluorescencyjnych NDs w ilościowej ocenie progresji nowotworu [113]. Również badania prowadzone na myszach $\mathrm{w}$ celu oceny zdolności regeneracyjnych komórek macierzystych płuc wskazują na zalety długoterminowej detekcji komórek za pomocą fluorescencyjnych NDs [114].

\section{ZASTOSOWANIE NANODIAMENTÓW W TERAPII PRZECIWNOWOTWOROWEJ}

W badaniach prowadzonych nad opracowaniem możliwości skutecznej walki z różnego rodzaju nowotworami, równie ważne jak odkrywanie nowych związków anty- 
neoplastycznych jest opracowanie sposobu efektywnego dostarczania już istniejących, skutecznych terapeutyków. NDs ze względu na ich biokompatybilność i brak wpływu na reakcje immunologiczne organizmu brane są pod uwagę jako alternatywny transporter chemioterapeutyków oraz innych leków wspomagających leczenie pacjentów ze zdiagnozowaną chorobą nowotworową $[3,5,14,17,18]$. Istnieje szereg doniesień naukowych, które spośród wielu badanych nanonośników rekomendują do tego celu użycie NDs $[20,26,31,42,43]$.

Badania in vitro koniugatów NDs z szeroko stosowanym cytostatykiem - doksorubicyną (DOX, ang. doxorubicin), wykazały powolne i wydłużone uwalnianie leku, w porównaniu z czasem odnotowanym po aplikacji wyłącznie DOX. Ponadto, $\mathrm{w}$ badaniach in vivo stwierdzono czterokrotnie większy wskaźnik przeżywalności myszy z rakiem wątroby, traktowanych koniugatem NDs-DOX w porównaniu ze wskaźnikiem przeżywania myszy, którym aplikowano jedynie DOX. Analiza histopatologiczna wykazała, że zarówno NDs, jak i NDs-DOX nie były toksyczne dla nerek, wątroby i śledziony, w przeciwieństwie do dobrze znanych efektów toksycznych wolnej DOX [115]. W innych badaniach, w celu zwiększenia wydajności koniugacji NDs z DOX, powierzchnię nanocząsteczek modyfikowano wprowadzając grupy hydroksylowe, karboksylowe lub aminowe, a także cząsteczki o większych rozmiarach, takie jak glikol polietylenowy lub fibroina jedwabiu. Wykorzystywano również różne podejścia polegające na wiązaniu DOX ze zmodyfikowaną powierzchnią NDs za pomocą wiązań kowalencyjnych lub fizycznej adsorpcji za pomocą wiązań wodorowych lub sił Van der Waalsa. Uzyskano w ten sposób nie tylko zwiększoną wydajność opłaszczenia powierzchni, lecz także większy stopień dyspersji, wychwytu komórkowego oraz uwalniania leku [116,117]. Badanie fluorescencyjnych NDs ze związaną DOX dowiodło, że dokomórkowy wychwyt obejmuje kompleks NDs-DOX, natomiast lek uwalniany jest dopiero w cytozolu komórek nowotworowych, co związane jest m.in. z kwaśnym pH cytoplazmy tych komórek [115]. Ta sama zależność potwierdzona została również dla cisplatyny, wskazując na wysoki wskaźnik uwalniania leku z kompleksu w komórkach nowotworowych, natomiast niewielki w krwioobiegu [118]. Stabilne i kontrolowane uwalnianie leku przez okres 14 dni obserwowano również w wodzie, PBS oraz pożywce proteazowej, przy czym szybkość uwalniania DOX zależna była od rodzaju zastosowanego medium [119]. Sfery NDs-DOX zawierające fibroinę jedwabiu doskonale spełniają swoje zadanie nie tylko jako nanonośnik, lecz dzięki emisji jaśniejszej fluorescencji umożliwiają dokładne obrazowanie biodystrybucji leku [117].

Kluczowym problemem będącym podstawową przyczyną niepowodzenia w leczeniu raka jest zjawisko chemooporności oraz wielolekowej oporności komórek nowotworowych. Dotyczy ono przede wszystkim nowotworowych komórek macierzystych, odpowiadających za regeneracje guza, co uniemożliwia skuteczne leczenie [120]. Alternatywą dla klasycznych metod przezwyciężenia oporności komórek macierzystych, takich jak jednorazowa aplikacja kilku chemioterapeutyków jest zastosowanie kompleksów NDs-lek [121]. Badania chemoopornej linii komórek guza wątroby i raka sutka wykazały, że kompleks NDs-DOX indukuje apoptozę komórek oraz hamuje wzrost guza przełamując zjawisko chemooporności [122]. Kompleks ten zastosowano również $\mathrm{w}$ badaniach oporności glejaka, nowotworu mózgu o szybkiej regeneracji za sprawą komórek macierzystych. Wykazując wyższe stężenie leku w komórkach guza traktowanego koniugatem w porównaniu z guzem traktowanym jedynie DOX potwierdzono, że NDs charakteryzuje nie tylko niski indeks egzocytarny, lecz także oporność na działanie systemów usuwających leki wykorzystywanych przez komórki nowotworowe, takich jak transportery ABC (ang. ATP-binding cassette transporter) [123]. Badania prowadzone na ksenograftach raka wątroby dowiodły, że zastosowanie koniugatów NDs z epirubicyną (EPI, ang. epirubicin) powoduje śmierć zarówno zróżnicowanych komórek nowotworowych (efekt charakterystyczny dla działania EPI), jak i komórek macierzystych nowotworu, zapobiegając powstawaniu guza wtórnego. Stwierdzono ponadto, że letalna dawka EPI stała się bezpieczna po związaniu jej z NDs, co potwierdza nie tylko skuteczność zwalczania macierzystych komórek chemoopornych, lecz także wskazuje na zahamowanie skutków ubocznych działania leku [124]. Podejście nanotechnologiczne z wykorzystaniem NDs może mieć więc duże znaczenie w przypadku chemioterapii u dzieci, osób w podeszłym wieku oraz innych pacjentów wykazujących niską tolerancję na toksyczne skutki uboczne działania większości chemioterapeutyków.

Zwiększenie skuteczności leczniczej chemioterapeutyków, można uzyskać również poprzez polepszenie za pomocą NDs ich właściwości dyspersyjnych, czego dowiedziono w przypadku paklitakselu (PTX, ang. paclitaxel). Skuteczną aktywność przeciwnowotworową tego leku obniża jego słaba dyspersja w środowisku wodnym, co skutkuje zmniejszoną biodostępnością. Koniugacja hydroksylowanych NDs z PTX spowodowała wzrost skuteczności działania leku wyrażony przedłużonym uwalnianiem oraz zwiększonym wychwytem komórkowym [125]. Skuteczność terapeutyczną PTX zwiększono opracowując nową metodę koniugacji wykorzystującą mikrofale, kwas stearynowy, trietyloaminę oraz chlorek metanosulfonylu. W porównawczym badaniu żywotności komórek gruczolakoraka płuc oraz raka jelita grubego, wykazano istotny wzrost śmiertelności komórek traktowanych koniugatem NDs-PTX utworzonym z wykorzystaniem mikrofal, w porównaniu z komórkami traktowanymi tym samym koniugatem syntetyzowanym klasycznymi metodami [126].

Innowacyjnym podejściem w leczeniu nowotworów wydaje się być wykorzystanie nanotechnologii w antynowotworowej terapii celowanej, $\mathrm{z}$ wykorzystaniem humanizowanych przeciwciał monoklonalnych [127]. Przeciwciała te skierowane są przeciwko wybranym antygenom komórek nowotworowych zwiększając efekt terapeutyczny. W tym celu projektowane są wielkoskładnikowe systemy dostarczania leku, oparte na znakowanym fluorescencyjnie nanodiamentowym rdzeniu, opłaszczonym PTX oraz dodatkowo przeciwciałem monoklonalnym specyficznym dla receptora czynnika wzrostu naskórka (EGFR, ang. epidermal growth factor receptor) [71]. W badaniach in vivo raka okrężnicy, przebadano skuteczność działania NDs skoniugowanych z silnym cytostatykiem cisplatyną oraz cetuksimabem, 
przeciwciałem monoklonalnym skierowanym swoiście przeciw EGFR. Badanie to potwierdziło selektywne wiązanie koniugatu z komórkami nowotworowymi uwarunkowane obecnością przeciwciał. Zwiększoną skuteczność terapeutyczną tego koniugatu $\mathrm{w}$ porównaniu $\mathrm{z}$ niezwiązaną cisplatyną stwierdzono także na liniach komórek ludzkiego raka wątroby [128]. Wyniki tych badań dowodzą, że koniugat NDs, składający się z dwóch składników, leku i specyficznego przeciwciała powoduje selektywne rozpoznawanie komórek nowotworowych, a tym samym obniża wskaźnik narażenia zdrowych komórek na cytotoksyczne działanie leku [129]. Badania potwierdzają, że doskonałymi kandydatami do projektowania specyficznych nanokoniugatów są również przeciwciała monoklonalne, takie jak trastuzumab skierowany przeciwko receptorom ludzkiego naskórkowego czynnika wzrostu (Her2, ang. human epidermal growth factor receptor), bewacizumab hamujacy neowasculogenezę nowotworową przez wiązanie z czynnikiem wzrostu śródbłonka naczyniowego (VEGF, ang. vascular endothelial growth factor) oraz edrekolomab skierowany przeciwko antygenowi 17-1A charakterystycznemu dla komórek nowotworowych przewodu pokarmowego [130-132].

Wzrost zainteresowania wykorzystaniem bioaktywnych metabolitów roślinnych w terapii przeciwnowotworowej spowodował, że związki te, podobnie jak klasyczne chemioterapeutyki, są sprzęgane z NDs [133]. Badania w których citropten oraz kwercetynę połączono z NDs o modyfikowanej różnymi grupami powierzchni, wykazały zróżnicowane działanie antyproliferacyjne w przypadku komórek mysiej linii czerniaka skóry oraz komórek HeLa, w zależności od rodzaju przeprowadzonej modyfikacji. Rodzaj modyfikacji powierzchni NDs w istotny sposób wpływa na efekt terapeutyczny regulując wiele kluczowych parametrów, takich jak: biodostępność, specyficzność i uwalnianie leku. Wykazano, że kompleks NDs z drugorzędowym metabolitem citroptenu hamował proliferację komórek czerniaka skóry przez zaburzenie cyklu komórkowego oraz syntezy mRNA [134].

NDs w terapii przeciwnowotworowej można stosować nie tylko jako nośniki chemioterapeutyków, lecz także innych leków wspomagających terapię, takich jak: leki przeciwbólowe, przeciwzapalne, przyspieszające gojenie ran, czy niwelujące skutki uboczne cytostatyków [135]. Biorąc pod uwagę możliwość topikalnej aplikacji NDs opłaszczonych lekami, wiele badań koncentruje się na opracowaniu chitozanowo-celulozowych kompozytów zawierających terapeutyczne nanokompleksy o przedłużonym uwalnianiu, które mogłyby znaleźć zastosowanie jako opatrunki [136]. Przeprowadzono badania wskazujące na większą zdolność dyspersji koniugatów NDs i deksametazonu, silnego środka przeciwzapalnego, w porównaniu z dyspersją niezwiązanego leku [137]. Wykorzystując linię mysich fibroblastów L929 potwierdzono biokompatybilność koniugatów NDs ze stosowanymi powszechnie niesteroidowymi lekami przeciwzapalnymi: aspiryną, ketoprofenem, ibuprofenem i naproksenem [31]. Funkcjonalizacja powierzchni NDs amoksycyliną, antybiotykiem $\beta$-laktamowym poprzedzona modyfikacją powierzchni polietylenoiminą, otwiera możliwości wykorzystania podejścia nanotechnologicznego w leczeniu nie tylko schorzeń nowotworowych, lecz także towarzyszących im zakażeń bakteryjnych [138]. Opracowanie koniugatu NDs-amoksycylina, z dodatkiem gutaperki, materiału stosowanego do wypełniania kanałów zębowych, wykazującego aktywność terapeutyczną sugeruje możliwość wykorzystania NDs w stomatologii, w przypadku leczenia kanałowego [20] (Ryc. 5A). Wykorzystanie nanotechnologii w leczeniu chorób bakteryjnych wspierają również wyniki badań, wskazujące na przeciwbakteryjną aktywność niefunkcjonalizowanych NDs, polegającą na hamowaniu tworzenia kolonii bakterii E. coli [139].

Z przeprowadzonych dotychczas badań wynika, że różnorodność modyfikacji powierzchni oraz szerokie możliwości funkcjonalizacji NDs fluorochromami oraz środkami terapeutycznymi, mogą być wykorzystane w przyszłości na szeroką skalę $\mathrm{w}$ diagnozie i leczeniu chorób nowotworowych, a także wielu schorzeń o innym podłożu $[44,46,56,60,61]$.

\section{WYKORZYSTANIE NANODIAMENTÓW W INŻYNIERII TKANKOWEJ}

Właściwości fizyko-chemiczne wynikające ze struktury NDs w połączeniu z ich biokompatybilnością oraz nieograniczonymi możliwościami funkcjonalizacji charakteryzują te nanocząsteczki jako prawie idealny materiał o potencjalnym zastosowaniu w inżynierii tkankowej $[20,67,108]$. Badania dotyczące możliwości wykorzystania NDs dla potrzeb medycyny regeneracyjnej koncentrują się głównie w obszarze inżynierii tkanki kostnej oraz nerwowej [36,37]. W tym przypadku NDs wykorzystano m.in. jako adhezyjne powłoki powierzchniowe rusztowań, powłoki poprawiające właściwości trybologiczne implantów oraz wypełniacze do wzmocnienia właściwości mechanicznych rusztowań kompozytowych [39,69] (Ryc. 5B). Funkcjonalizacja NDs białkami takimi jak fibronektyna czy witronektyna ułatwia adhezję różnych typów komórek, a modyfikacja chemiczna i topografia ich powierzchni może zostać wykorzystana w kontroli ich różnicowania [140,141]. Wzbogacając implanty biomedyczne o wyskalowane warstwowe powłoki NDs można w istotny sposób wpłynąć na właściwości adhezyjne komórek. Badania z wykorzystaniem NDs o różnej hydrofilowości oraz mezenchymalnych komórek macierzystych szczura, wykazały zwiększoną adhezję osteoblastów na biofilmach zawierających bardziej hydrofilowe NDs [142]. Optymalizację aktywności biologicznej implantu uzyskano również wykorzystując karboksylowane NDs do opracowania rusztowania kostnego z polilaktydu i polikaprolaktonu. Wprowadzenie tego rusztowania spowodowało całkowitą regenerację defektów kostnych u owcy w ciągu dwudziestu czterech tygodni, w przeciwieństwie do częściowej regeneracji uzyskanej po zastosowaniu rusztowania bez NDs [35]. Wyniki badań in vitro wskazują na istotny wzrost ekspresji markerów osteogennych ludzkich komórek mezenchymalnych na rusztowaniach polimerowych zawierających NDs o hydrofilowej powierzchni [36]. Topografia powierzchni rusztowania zawierającego NDs ułatwia zakotwiczenie mezenchymalnych komórek macierzystych, co wynika ze zwiększenia chropowatości jego powierzchni w nanoskali [142]. W innych badaniach wykazano, że obecność NDs o utlenionej powierzchni zwiększa właściwości osteoindukcyjne hydroksyapatytu [140]. Występowanie grup funkcyj- 


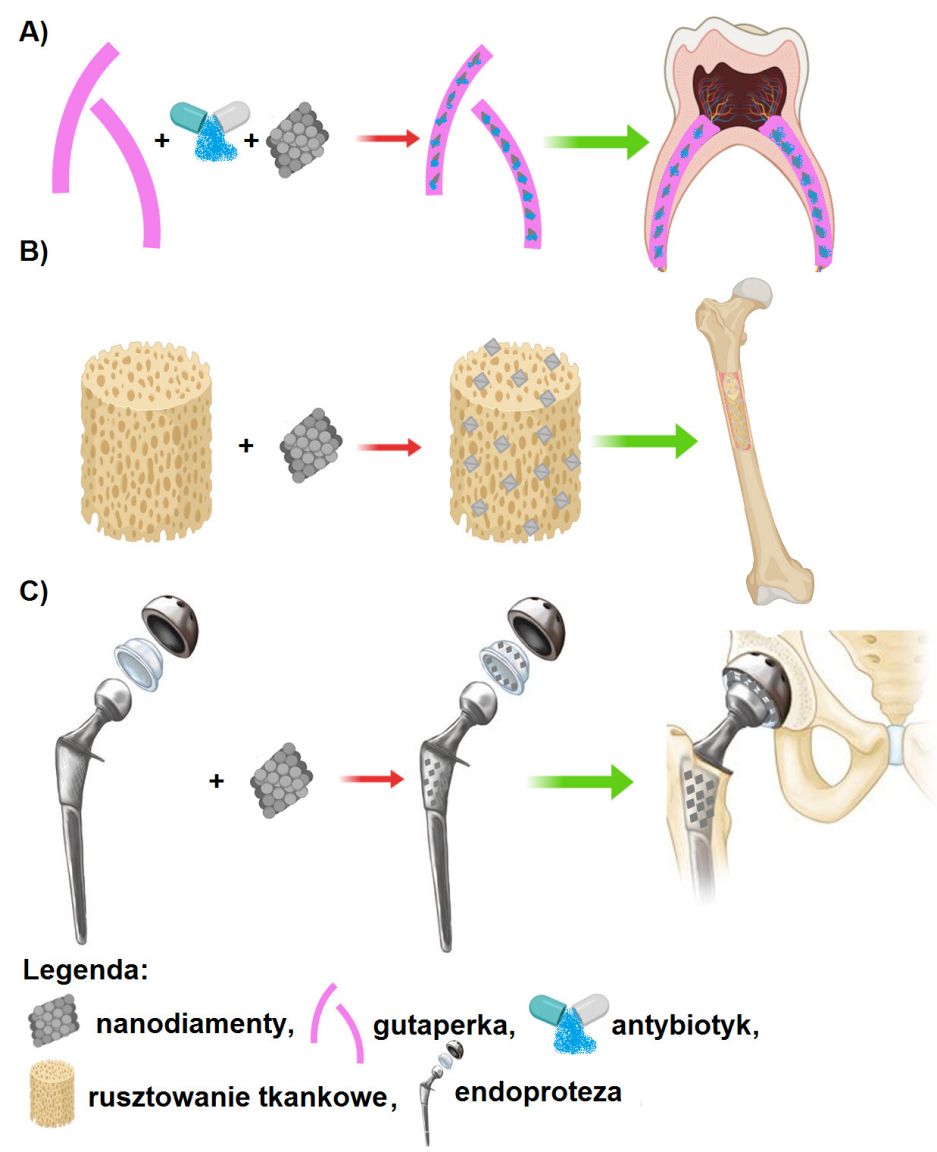

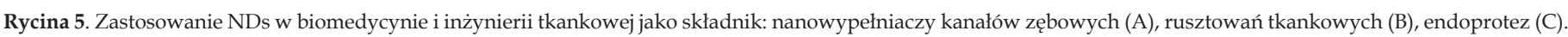

nych z dodatnim ładunkiem na powierzchni NDs obecnych w powłoce apatytowej wzmaga adsorpcję fibronektyny, co spowodowane jest zmianą hydrofobowości podłoża [143]. Osteoblasty oprócz zwiększonej przyczepności do rusztowania apatytowego zawierającego NDs, wykazywały również wzmożoną zdolność do reorganizacji fibronektyny [144].

Oprócz wzmagania bioaktywności rusztowań kostnych, NDs mogą być również wykorzystane dla potrzeb inżynierii tkanki nerwowej [37]. Hodowla neuronów in vitro wymaga zastosowania substratów laminowanych białkami macierzy zewnątrzkomórkowej, takimi jak laminina lub syntetycznymi związkami np. polilizyną [145]. Z uwagi na cytotoksyczność polilizyny, możliwość wykorzystania tego polimeru in vivo jest bardzo ograniczona [146]. Wskazując na wysoką biozgodność NDs, nanocząsteczki te zaproponowano jako potencjalny substrat dla wzrostu i różnicowania komórek nerwowych, który wykorzystać można do opracowania biokompatybilnych protez nerwowych. Wiele badań w tym zakresie przeprowadzono na nanorurkach węglowych, jednak $\mathrm{z}$ powodu cytotoksyczności tych nanostruktur, NDs wydają się bardziej odpowiednie do zastosowania przy produkcji implantów klinicznych $[42,45,147]$. Doniesiono także o wpływie nanorurek węglowych na zmiany w przekazywaniu sygnałów nerwowych, podczas gdy NDs nie wpływały na generowanie potencjałów czynnościowych [148]. Monowarstwy zawierające NDs z ulokowanym tlenem na powierzchni wzmagają adhezję i wydłużanie neurytów pierwotnych neuronów hipokampa $\mathrm{w}$ takim samym stopniu, jak syntetyczne podłoża kontrolne $z$ lamininy [37]. Na podłożach zawierających NDs obserwowano kluczowe dla powstania funkcjonalnych obwodów neuronalnych rozgałęzienie neurytów oraz neurotransmisję. Badania korelacji adhezji komórek nerwowych i elongacji neurytów z morfologią NDs wykazały również, że mniejsze i bardziej sferyczne NDs, naśladując białka macierzy zewnątrzkomórkowej, wspierają tworzenie bardziej rozbudowanych sieci neuronowych. Modyfikacja chemiczna powierzchni NDs nie wpływała bezpośrednio na wydłużanie neurytów, jednak adsorpcja białek, takich jak fibronektyna czy witronektyna wzmagała adhezję i wzrost neuronów [141]. Inne badania wykazały wzrost adhezji komórek nerwowych glejaka, lemocytów oraz zwoju korzenia grzbietowego na podłożu zawierającym NDs z grupami aminowymi [149].

Zainteresowanie NDs $\mathrm{w}$ inżynierii tkankowej wzrasta również ze względu na możliwość poprawy właściwości trybologicznych implantów i protez stawowych przez nanodiamentowe powłoki (Ryc. 5C), co pozwoli przezwyciężyć szereg problemów związanych z długotrwałą eksploatacją protezy, takich jak: powstawanie drobnych odłamków powodujących ból stawów, osteolizę oraz obluzowanie implantu [150]. Stwierdzono również, że nanodiamentowe powłoki poprawiają odporność implantów na zużycie i zapobiegają uwalnianiu jonów metali z implantów kolan, bioder, stawu skroniowo-żuchwowego, implantów dentystycznych oraz stentów naczyniowych [151-155]. 
Duży stosunek powierzchni do objętości oraz obecność licznych reaktywnych grup funkcyjnych na powierzchni NDs sprawia, że nanocząsteczki te jako składniki polimerów i wielofunkcyjnych nanokompozytów, poprawiają ich biokompatybilność, właściwości mechaniczne oraz biomimetyczne naśladując hierarchiczną architekturę natywnej tkanki $[3,20,38]$. Wykorzystując technikę elektroprzędzenia opracowano rusztowanie tkankowe z kaprolaktonu, w którym obecność NDs powodowała polepszenie właściwości mechanicznych polegające na zwiększeniu możliwości rozciągania, porównywalne $\mathrm{z}$ właściwościami istoty gąbczastej kości [39]. Wykazano również, że rusztowanie będące kopolimerem polilaktydu i poliglikolidu z dodatkiem NDs charakteryzowało się większą sprężystością i wytrzymałością. W innych badaniach potwierdzono, że NDs zwiększają wytrzymałość alkoholu poliwinylowego, który jest szeroko stosowany przy produkcji implantów, na rozciąganie, nici chirurgicznych czy sztucznych narządów [156].

Jedynym ograniczeniem związanym z wykorzystaniem NDs w produkcji implantów i rusztowań tkankowych jest ich zdolność do agregacji, co wymusza konieczność stosowania nanocząsteczek $\mathrm{w}$ odpowiednio wyważonej ilości [157]. Problem agregacji można jednak przezwyciężyć poprzez wprowadzenie kowalencyjnych modyfikacji zwiększających stabilność i właściwości dyspersyjne NDs $[21,82,84]$. W tym celu opracowano koniugat składający się z NDs zawierających na powierzchni grupy aminowe połączone kowalencyjnie z żywicą epoksydową. Uzyskano $\mathrm{w}$ ten sposób znaczny wzrost twardości $\mathrm{w}$ porównaniu $\mathrm{z}$ nanokompozytami, które nie tworzyły z żywicą kowalencyjnych połączeń [158]. Z kolei po kowalencyjnym połączeniu NDs z oktadecyloaminą, kompleks ten wykorzystano w wytworzeniu rusztowania z polilaktydu, uzyskując dwukrotny wzrost odkształcalności liniowej oraz ośmiokrotny wzrost twardości, porównywalny z twardością powierzchniowej warstwy nasad kości [159]. Wykazano również że NDs opłaszczone fosfolipidami można włączyć w skład rusztowań z polimeru polilaktyd-glikolid, co pozwala uzyskać wzrost twardości oraz sprężystości podłużnej, w porównaniu do rusztowań wykonanych z czystego polimeru. Badania in vivo prowadzone na myszach potwierdzają, że nanokompozyty zawierające NDs wspomagają proliferację i wzrost komórek, jednocześnie nie indukując odpowiedzi immunologicznej [160].

Nowym podejściem proponowanym $\mathrm{w}$ inżynierii tkankowej jest multifunkcjonalne wykorzystanie właściwości NDs zarówno jako nanowypełniacza ulepszającego właściwości trybologiczne implantów, jak i nanonośnika uwalniającego substancje biologicznie czynne [20,67]. Implanty zaprojektowane $\mathrm{z}$ domieszką NDs funkcjonalizowanych bioaktywnymi związkami będą spełniać nie tylko funkcję odpowiednio wytrzymałego i sprężystego rusztowania, lecz także uwalniać terapeutyczne substancje przyspieszające $n p$. osteogenezę, gojenie ran lub uśmierzające ból w obrębie stawu $[31,69,138]$. Poprzez funkcjonalizację NDs białkiem morfogenetycznym kości, a następnie włączenie tego kompleksu do kopolimeru kwasu L-mlekowego i kaprolaktonu stwierdzono in vivo ulepszenie aktywności osteogenicznej implantu wynikające z przedłużonego uwal- niania białkowego czynnika morfogenetycznego. Ponadto, powłoki te wykazywały miejscowe działanie przeciwzapalne [161]. Powłoki powierzchniowe zawierające NDs zastosowano również $\mathrm{w}$ celu przedłużonego uwalniania angiogennych czynników wzrostu z rusztowań $\beta$-fosforanu triwapnia $w$ celu przyspieszenia regeneracji kości [162]. Niekowalencyjne przyłączenie VEGF oraz angiopoetyny do utlenionej powierzchni NDs, a następnie wbudowanie tego kompleksu do rusztowań, którymi wypełniono ubytki kości owczej, skutkowało powstaniem znacznie gęstszej sieci naczyń krwionośnych o większej średnicy w porównaniu z naczyniami powstałymi po implantacji rusztowania pozbawionego kompleksu [163]. Tego rodzaju podejście polegające na multifunkcjonalnym wykorzystaniu NDs, może $\mathrm{w}$ przyszłości znaleźć szerokie zastosowanie w medycynie regeneracyjnej $[20,36,37,39,40]$.

\section{PODSUMOWANIE}

Badania prowadzone $\mathrm{z}$ wykorzystaniem NDs, sugerują możliwość praktycznego zastosowania tych unikalnych nanocząsteczek $\mathrm{w}$ wielu naukach i dziedzinach życia, takich jak biologia, chemia, medycyna, rolnictwo, przemysł spożywczy, fizyka, przemysł maszynowy, budownictwo i transport $[5,17,18,62,67]$. Możliwość funkcjonalizacji powierzchni NDs związkami biologicznie aktywnymi może przyczynić się do opracowania wielu nanotechnologicznych, terapeutycznych rozwiązań charakteryzujących się wyższą skutecznością niż stosowane dotąd metody $[70,73,86,111,115]$. Zastosowanie NDs w biomedycynie i biotechnologii pozwoli również na przezwyciężenie wielu ograniczeń natury biochemicznej, jak np. penetracja peptydu przez wielowarstwową i hydrofobową kutikulę owada, przy zachowaniu aktywności biologicznej peptydu, bioobrazowanie z zachowaniem wyraźnej i długotrwałej fluorescencji czy dostarczanie do komórek nowotworowych i utrzymywanie $\mathrm{w}$ nich związków terapeutycznych [50,56,60,121,125]. Z tego powodu NDs wyróżniają się nie tylko na tle innych nanocząsteczek, lecz jak dotąd stanowią także bezkonkurencyjny materiał spośród wszystkich znanych nanostruktur węglowych $[15,18,23,33,71]$.

\section{PIŚMIENNICTWO}

1. Ciftan Hens S, Cunningham G, McGuire G, Shenderova O (2011) Nanodiamond-assisted dispersion of carbon nanotubes and hybrid nanocarbon-based composites. Nanosci Nanotechnol Lett 3: 1-8

2. Kristianto H, Putra CD, Arie AA, Halim M, Lee JK (2015) Synthesis and characterization of carbon nanosphaeres using cooking palm oil as natural precursors of onto activated carbon support. Procedia Chem 16: 328-333

3. Zhu Y, Li J, Li W, Zhang Y, Yang X, Chen N, Sun Y, Zhao Y, Fan Ch, Huang Q (2012) The biocompatibility of nanodiamonds and their application in drug delivery systems. Theranostics 2: 302-312

4. Lin Y, Sun X, Su DS, Centi G, Perathoner S (2018) Catalysis by hybrid $\mathrm{sp}^{2} / \mathrm{sp}^{3}$ nanodiamonds and their role in the design of advanced nanocarbon materials. Chem Soc Rev 47:8438-8473

5. Mishra R, Chhalodia AK, Tiwari SK (2018) Recent progress in nanodiamonds: synthesis, properties and their potential applications. Veruscript Funct Nanomater 2: \#8W2EG0 https://doi.or$\mathrm{g} / 10.22261 / 8 \mathrm{~W} 2 \mathrm{EG} 0$

6. Stehlik S, Varga M, Ledinsky M, Jirasek V, Artemenko A, Kozak H, Ondic L, Skakalova V, Argentero G, Pennycook T, Meyer JC, Fejfar A, Kromka A, Rezek B (2015) Size and purity control of HPHT nano- 
diamonds down to $1 \mathrm{~nm}$. J Phys Chem C Nanomater Interfaces 119: 27708-27720

7. Kumar A, Lin PA, Xue A, Hao B, Yap YK, Sankaran M (2014) Formation of nanodiamonds at near-ambient conditions via microplasma dissociation of ethanol vapour. Nat Commun 1-8 https://doi. org $/ 10.1038 /$ ncomms3618

8. Amans D, Chenus AC, Ledoux G, Dujardin Ch, Reynaud C, Sublemontier O, Masenelli-Varlot K, Guillois O (2009) Nanodiamond synthesis by pulsed laser ablation in liquids. Diam Relat Mater 18: 177-180

9. Boudou JP, Curmi P, Jelezko F, Wrachtrup J, Aubert P, Sennour M, Balasubramanian G, Reuter R, Thorel A, Gaffet E (2009) High yield fabrication of fluorescent nanodiamonds. Nanotechnology 20: https:// doi.org/10.1088/0957-4484/20/23/235602

10. Ischenko V, Jang YS, Kormann M, Greil P, Popovska N, Zollfrank C, Woltersdorf J (2011) The effect of SiC substrate microstructure and impurities on the phase formation in carbide-derived carbon. Carbon 49: 1189-1198

11. Khachatryan AK, Aloyan SG, May PW, Sargsyan R, Khachatryan VA, Baghdasaryan VS (2008) Graphite-to-diamond transformation induced by ultrasound cavitation. Diam Relat Mater 17: 931-936

12. Daulton TL, Kirk MA, Lewis RS, Rehn LE (2001) Production of nanodiamonds by high-energy ion irradiation of graphite at room temperature. Nucl Instrum Methods Phys Res Sect B 175-177: 12-20

13. Afandi A, Howkins A, Boyd IW, Jackman RB (2018) Nanodiamonds for device applications: an investigation of the properties of boron-doped detonation nanodiamonds. Sci Rep 8: 3270 https://doi. org/10.1038/s41598-018-21670-w

14. Datta A, Kirca M, Fu Y, To AC (2010) Surface structure and properties of functionalized nanodiamonds: a first-principles study. Nanotechnology 22(6): 065706 https://doi.org/10.1088/0957-4484/22/6/065706

15. Magrez A, Kasas S, Salicio V, Pasquier N, Seo JW, Celio M, Catsicas S, Schwaller B, Forro L (2006) Cellular toxicity of carbon-based nanomaterials. Nano Lett 6: 1121-1125

16. Pichot V, Comet M, Fousson E, Baras C, Senger A, Le Normand F, Spitzer D (2008) An efficient purification method for detonation nanodiamonds. Diam Relat Mater 17: 13-22

17. Kaur R, Badea I (2013) Nanodiamonds as novel nanomaterials for biomedical applications: drug delivery and imaging systems. Int J Nanomedicine 8: 203-220

18. Georgakilas V, Perman JA, Tucek J, Zboril R (2015) Broad family of carbon nanoallotropes: classification, chemistry and applications of fullerenes, carbon dots, nanotubes, graphene, nanodiamonds and combined superstructures. Chem Rev 115: 4744-4822

19. Mitev DP, Townsend AT, Paull B, Nesterenko PN (2014) Microwave-assisted purification of detonation nanodiamond. Diam Relat Mater 48: $37-46$

20. Turcheniuk K, Mochalin VN (2017) Biomedical applications of nanodiamond (Review). Nanotechnology 28: 252001 https://doi. org/10.1088/1361-6528/aa6ae4

21. Krüger A, Kataoka F, Ozawa M, Fujino T, Suzuki Y, Aleksenskii AE, Vul AY, Osawa E (2005) Unusually tight aggregation in detonation nanodiamond: identification and disintegration. Carbon 43: 1722-1730

22. Skaltsas T, Pispas S, Tagmatarchis N (2015) Non-covalent nanodiamond-polymer dispersions and electrostatic immobilization of bovine serum albumin protein. Mater Res Express 2 115005. https://doi. org/10.1088/2053-1591/2/11/115005

23. Maitra U, Gomathi A, Rao CNR (2009) Covalent and noncovalent functionalisation and solubilisation of nanodiamond. J Exp Nanosci 3: 271-278

24. Martin R, Alvaro M, Herance JR, Garcia H (2010) Fenton-treated functionalized diamond nanoparticles as gene delivery system. ACS Nano 4: 65-74

25. Adach K, Fijalkowski M, Skolimowski J (2015) Antioxidant effect of hydroxylated diamond nanoparticles measured in soybean oil. Fuller Nanotub Car N 23: 12 1024-1032
26. Lim DG, Kim KH, Kang E, Lim SH, Ricci J, Sung SK, Kwon MT, Jeong SH (2016) Comprehensive evaluation of carboxylated nanodiamond as a topical drug delivery system. Int J Nanomedicine 11: 2381-2395

27. Hens SC, Cunningham G, Tyler T, Moseenkov S, Kuznetsov V, Shenderova O (2008) Nanodiamond bioconjugate probes and their collection by electrophoresis. Diam Relat Mater 17: 1858-1866

28. Hsu MH, Chuang H, Cheng FY, Huang YP, Han CC, Chen JY, Huang SC, Chen JK, Wu DS, Chu HL, Chang CC (2014) Directly thiolated modification onto the surface of detonation nanodiamonds. ACS Appl Mater Interfaces 6: 7198-7203

29. Say JM, van Vreden C, Reilly DJ, Brown LJ, Rabeau JR, King NJC (2011) Luminescent nanodiamonds for biomedical applications. Biophys Rev 3: 171-184

30. Huang LCL, Chang HC (2004) Adsorption and immobilization of cytochrome $\mathrm{c}$ on nanodiamonds. Langmuir 20: 5879-5884

31. Mitura K, Wilczek P, Niemiec-Cyganek A, Morenc M, Dudek M, Sobczyk-Guzenda A, Fraczyk J, Kolesińska B (2017) Detonation nanodiamond particles modified by non-steroidal anti-inflammatory drugs in vitro examination. Engineering of Biomaterials 20: 12-20

32. Spitsyn BV, Davidson JL, Gradoboev MN, Galushko TB, Serebryakova NV, Karpukhina TA, Kulakova II, Melnik NN (2006) Inroad to modification of detonation nanodiamond. Diam Relat Mater 15: 296-299

33. Liu Y, Gu Z, Margrave JL, Khabashesku VN (2004) Functionalization of nanoscale diamond powder: fluoro-, alkyl-, amino-, and amino acid-nanodiamond derivatives. Chem Mater 16: 3924-3930

34. Liu Y, Khabashesku VN, Halas NJ (2005) Fluorinated nanodiamond as a wet chemistry precursor for diamond coatings covalently bonded to glass surface. J Am Chem Soc 127: 3712-3713

35. Xing Z, Pedersen TO, Wu X, Xue Y, Sun Y, Finne-Wistrand A, Kloss FR, Waag T, Krueger A, Steinmüller-Nethl D, Mustafa K (2013) Biological effects of functionalizing copolymer scaffolds with nanodiamond particles. Tissue Eng Part A 19: 1783-1791

36. Yassin MA, Mustafa K, Xing Z, Sun Y, Fasmer KE, Waag T, Krueger A, Steinmüller-Nethl A, Finne-Wistrand A, Leknes KN (2017) A copolymer scaffold functionalized with nanodiamond particles enhances osteogenic metabolic activity and bone regeneration. Macromol Biosci 17: https://doi.org/10.1002/mabi.201600427

37. Thalhammer A, Edgington RJ, Cingolani LA, Schoepfer R, Jackman RB (2010) The use of nanodiamond monolayer coatings to promote the formation of functional neuronal networks. Biomaterials 31: 2097-2104

38. Whitlow J, Pacelli S, Paul A (2016) Polymeric nanohybrids as a new class of therapeutic biotransporters. Macromol Chem Phys 217: 12451259

39. Salaam AD, Dean D (2010) Electrospun polycaprolactone-nanodiamond composite scaffolds for bone tissue engineering. Tissue Eng 43925: 367-370

40. Zhang X, Fu C, Feng L, Ji Y, Tao L, Huang Q, Huang H, Tian J, Jiang R, Wen Y, Zhang X, Wei Y (2012) PEGylation and polyPEGylation of nanodiamond. Polymer 53: 3178-3184

41. Schrand AM, Huang H, Carlson C, Schlager JJ, Osawa E, Hussain SM, Dai L (2007) Are diamond nanoparticles cytotoxic? J Phys Chem B 111 2-7

42. Schrand AM, Dai L, Schlager JJ, Hussain SM, Osawa E (2007) Differential biocompatibility of carbon nanotubes and nanodiamonds. Diam Relat Mater 16: 2118-2123

43. Liu KK, Cheng CL, Chang CC, Chao JI (2007) Biocompatible and detectable carboxyled nanodiamond on human cell. Nanotechnology 18 https://doi.org/10.1088/0957-4484/18/32/325102

44. Liu KK, Wang CC, Cheng CI, Chao JI (2009) Endocytic carboxylated nanodiamond for the labeling and tracking of cell division and differentiation in cancer and stem cells. Biomaterials 30: 4249-4259

45. Zhang X, Hu W, Li J, Tao L, Wei Y (2012) A comparative study of cellular uptake and cytotoxicity of multi-walled carbon nanotubes, graphene oxide, and nanodiamond. Tox Res 1: 62-68

46. Huang H, Pierstorff E, Osawa E, Ho D (2007) Active nanodiamond hydrogels for chemotherapeutic delivery. Nano Lett 7: 3305-3314 
47. Xing Y, Xiong W, Zhu L, Osawa L, Hussin S, Dai L (2011) DNA damage in embryonic stem cells caused by nanodiamonds. ACS Nano 5: 2376-2384

48. Marcon L, Riquet F, Vicogne D, Szunerits S, Bodart JF, Boukherroub R (2010) Cellular and in vivo toxicity of functionalized nanodiamond in Xenopus embryos. J Mater Chem 20: 8064-8069

49. Avsievich T, Popov A, Bykov A, Meglinski I (2019) Mutual interaction of red blood cells influenced by nanoparticles. Sci Rep 9: $5147 \mathrm{https}: / /$ doi.org/10.1038/s41598-019-41643-x

50. Czarniewska E, Nowicki P, Kuczer M, Schroeder G (2019) Impairment of the immune response after transcuticular introduction of the insect gonadoinhibitory and hemocytotoxic peptide Neb-colloostatin: A nanotech approach for pest control. Sci Rep 9: 10330 https://doi. org/10.1038/s41598-019-46720-9

51. Huang KJ, Lee CY, Lin YC, Lin CY, Perevedentseva E, Hung SF, Cheng CL (2017) Phagocytosis and immune response studies of macrophage-nanodiamond interactions in vitro and in vivo. J Biophotonics 10: 13151326

52. Karpeta-Kaczmarek J, Dziewięcka M, Augustyniak M, Rost-Roszkowska M (2016) Effects of short-term exposure of Acheta domesticus to nanodiamonds in food: DNA damage but no histological alternation in tissues. Carbon 110: 458-468

53. Yuan Y, Wang X, Jia G, Liu JH, Wang T, Gu Y, Yang ST, Zhen S, Wang H, Liu Y (2010) Pulmonary toxicity and translocation of nanodiamonds in mice. Diam Relat Mater 19: 291-299

54. Zhang X, Yin J, Kang C, Li J, Zhu Y, Li W, Huang Q, Zhu Z (2010) Biodistribution and toxicity of nanodiamonds in mice after intratracheal instillation. Toxicol Lett 198: 237-243

55. Mendonca E, Diniz M, Silva L, Peres I, Castro L, Correia JB, Picado A (2011) Effects of diamond nanoparticle exposure on the internal structure and reproduction of Daphnia magna. J Hazard Mater 186: 265-271

56. Vaijayanthimala V, Cheng PY, Yeh SH, Liu KK, Hsiao CH, Chao JI, Chang HC (2012) The long-term stability and biocompatibility of fluorescent nanodiamond as an in vivo contrast agent. Biomaterials 33: 7794-7802

57. Puzyr AP, Bondar VS, Selimhanova ZY, Tyan AG, Bortnikov EV, Injevatkin EV (2004) Dynamics of the selected physiological responses in laboratory mice under the prolonged oral administration of nanodiamond suspentions. Sib Med Obozr 4

58. Moore L, Yang J, Lan TTH, Osawa E, Lee DK, Johnson WD, Jianzhong X, Chow EKH, Ho D (2016) Biocompatibility assessment of detonation nanodiamond in non-human primates and rats using histological, hematologic, and urine analysis. ACS Nano 10: 7385-7400

59. Huang YA, Kao CW, Liu KK, Huang HS, Chiang MH, Soo CR, Chang HC, Chiu TW, Chao JI, Hwang E (2014) The effect of fluorescent nanodiamonds on neuronal survival and morphogenesis. Sci Rep 4: 6919 https://doi.org/10.1038/srep06919

60. Nunn N, d'Amora M, Prabhakar N, Panich AM, Froumin N, Torelli MD, Vlasov I, Reineck P, Gibson B, Rosenholm JM, Giordani S, Shenderova O (2018) Fluorescent single-digit detonation nanodiamond for biomedical applications. Methods Appl Fluoresc 6: 035010 https:// doi.org/10.1088/2050-6120/aac0c8

61. Ansari SA, Satar R, Jafri MA, Rasool M, Ahmad W, Zaidi SK (2016) Role of nanodiamonds in drug delivery and stem cell therapy. Iran J Biotechnol 14: 130-141

62. Hemelaar SR, van der Laan KJ, Hinterding SR, Koot MV, Ellermann E, Perona-Martinez FP, Roig D, Hommelet S, Novarina D, Takahashi H, Chang M, Schirhagl R (2017) Generally applicable transformation protocols for fluorescent nanodiamond internalization into cells. Sci Rep 7: 5862 https:/ / doi.org/10.1038/s41598-017-06180-5

63. Suarez-Kelly LP, Campbell AR, Rampersaud IV, Bumb A, Wang MS, Butchar JP, Tridandapani S, Yu L, Rampersaud AA, Carson WE (2017) Fluorescent nanodiamonds engage innate immune effector cells: a potential vehicle for targeted anti-tumor immunotherapy. Nanomedicine 13: 909-920

64. Perevedentseva E, Hong SF, Huang KJ, Chiang IT, Lee CY, Tseng YT, Cheng CL (2013) Nanodiamond internalization in cells and the cell uptake mechanism. J Nanopart Res 15: 1834 https://doi. org/10.1007/s11051-013-1834-8

65. Faklaris O, Joshi V, Irinopoulou T, Tauc P, Sennour M, Girard H, Gesset C, Arnault JC, Thorel A, Boudou JP, Curmi PA, Treussart F (2009) Photoluminescent diamond nanoparticles for cell labeling: study of the uptake mechanism in mammalian cells. ACS Nano 3: 3955-3962

66. Yang J, Kopecek J (2014) Macromolecular therapeutics. J Control Release 28: 288-303

67. Mochalin VN, Shenderova O, Ho D, Gogotsi Y (2012) The properties and application of nanodiamonds. Nat Nanotechnol 7: 11-23

68.Shimkunas RA, Robinson E, Lam R, Lu S, Xu X, Zhang XQ, Huang $\mathrm{H}$, Osawa E, Ho D (2009) Nanodiamond-insulin complexes as $\mathrm{pH}$ -dependent protein delivery vehicles Biomaterials 30: 5720-5728

69. Moore L, Gatica M, Kim H, Osawa E, Ho D (2013) Multi-protein delivery by nanodiamonds promotes bone formation. J Dent Res 92: 976-981

70.Smith AH, Robinson EM, Zhang XQ, Chow EK, Lin Y, Osawa E, Xi J, Ho D (2011) Triggered release of therapeutic antibodies from nanodiamond complexes. Nanoscale 3: 2844-2848

71.Zhang XQ, Lam R, Xu X, Chow EK, Kim HJ, Ho D (2011) Multimodal nanodiamond drug delivery carriers for selective targeting, imaging, and enhanced chemotherapeutic efficacy. Adv Mater 23 4770-4775

72.Wang HD, Yang Q, Niu CH (2010) Functionalization of nanodiamond particles with N,O-carboxymethyl chitosan. Diam Relat Mater 19: 441-444

73.Purtov KV, Petunin AI, Burov AE, Puzyr AP, Bondar VS (2010) Nanodiamonds as carriers for address delivery of biologically active substances. Nanoscale Res Lett 5: 631-636

74.Jia LT, Chen SY, Yang AG (2012) Cancer gene therapy targeting cellular apoptosis machinery. Cancer Treat Rev 38: 868-876

75. Lee CS, Bishop ES, Zhang R, Yu X, Farina EM, Yan S, Zhao C, Zeng Z, Shu Y, Wu X, Lei J, Li Y, Zhang W, Yang C, Wu K, Wu Y, Ho S, Athiviraham A, Lee MJ, Wolf JM, Reid RR, He TC (2017) Adenovirus-mediated gene delivery: Potential applications for gene and cell-based therapies in the new era of personalized medicine. Genes Dis 4: 43-63

76.Zhang XQ, Chen M, Lam R, Xu X, Osawa E, Ho D (2009) Polymer-functionalized nanodiamond platforms as vehicles for gene delivery. ACS Nano 3: 2609-2616

77. Alhaddad A, Adam MP, Botsoa J, Dantelle G, Perruchas S, Gacoin T, Mansuv C, Lavielle S, Malvy C, Treussart F, Bertrand JR (2011) Nanodiamond as a vector for siRNA delivery to Ewing sarcoma cells. Small 7: 3087-3095

78. Lim DG, Rajasekaran N, Lee D, Kim NA, Jung HS, Hong S, Shin YK, Kang E, Jeong SH (2017) Polyamidoamine-decorated nanodiamonds as a hybrid gene delivery vector and siRNA structural characterization at the charged interfaces. ACS Appl Mater Interfaces 9: 31543-31556

79. Claveau S, Bertrand JR, Treussart F (2018) Fluorescent nanodiamond applications for cellular process sensing and cell tracking. Micromachines 9: 247 https:/ / doi.org/10.3390/mi9050247

80. Yan J, Estevez MC, Smith JE, Wang K, He X, Wang L, Tan W (2007) Dye-doped nanoparticles for bioanalysis. Nano Today 2: 44-50

81. Medintz IL, Uyeda HT, Goldman ER, Mattoussi H (2005) Quantum dot bioconjugates for imaging, labelling and sensing. Nat Mater 4: 435446

82. Liu Y, Mao L, Liu X, Liu M, Xu D, Jiang R, Deng F, Li Y, Zhang X, Wei $Y$ (2017) A facile strategy for fabrication of aggregation-induced emission (AIE) active fluorescent polymeric nanoparticles (FPNs) via post modification of synthetic polymers and their cell imaging. Mater Sci Eng C Mater Biol Appl 79: 590-595

83. Cao QY, Jiang R, Liu M, Wan Q, Xu D, Tian J, Huang H, Wen Y, Zhang X, Wei Y (2017) Microwave-assisted multicomponent reactions for rapid synthesis of AIE-active fluorescent polymeric nanoparticles by 
post-polymerization method. Mater Sci Eng C Mater Biol Appl 80: 578583

84. Jiang R, Liu M, Chen T, Huang H, Huang Q, Tian J, Wen Y, Cao QY, Zhang X, Wei Y (2018) Facile construction and biological imaging of cross-linked fluorescent organic nanoparticles with aggregation-induced emission feature through a catalyst-free azide-alkyne click-reaction. Dyes Pigments 148: 52-60

85. Zhang X, Wang S, Xu L, Feng L, Ji Y, Tao L, Li S, Wei Y (2012) Biocompatible polydopamine fluorescent organic nanoparticles: facile preparation and cel imaging. Nanoscale 4: 5581-5584

86. Liu M, Ji J, Zhang X, Zhang X, Yang B, Deng F, Li Z, Wang K, Yang Y, Wei Y (2015) Self-polymerization of dopamine and polyethyleneimine: novel fluorescent organic nanoprobes for biological imaging applications. J Mater Chem B 3: 3476-3482

87. Popov M, Churkin V, Kirichenko A, Denisov V, Ovsyannikov D, Kulnitskiy B, Perezhogin I, Aksenenkov V, Blank V (2017) Raman spectra and bulk modulus of nanodiamond in a size interval of $2-5 \mathrm{~nm}$. Nanoscale Res Lett 12: 561 https:/ / doi.org/10.1186/s11671-017-2333-0

88. Cheng CY, Perevedentseva E, Tu JS, Chung PH, Cheng CL (2007) Direct and in vitro observation of growth hormone receptor molecules in A549 human lung epithelial cells by nanodiamond labeling. Appl Phys Lett 90: 163903 https:/ / doi.org/10.1063/1.2727557

89. Prabhakar N, Rosenholm JM (2019) Nanodiamonds for advanced optical bioimaging and beyond. Curr Opin Colloid Interface Sci 39: 220231

90. Xiao J, Liu P, Li L, Yang G (2015) Fluorescence origin of nanodiamonds. J Phys Chem C 119: 2239-2248

91. Hemelaar SR, de Boer P, Chipaux M, Zuidema W, Hamoh T, Martinez FP, Nagl A, Hoogenboom JP, Giepmans BNG, Schirhagl R (2017) Nanodiamonds as multi-purpose labels for microscopy. Sci Rep 7: 720 https:// doi.org/10.1038/s41598-017-00797-2

92. Kang RH, Baek SW, Ryu TK, Choi SW (2018) Fabrication of blue fluorescent nanodiamonds modified with alkyl isocyanate for cellular bioimaging. Colloids Surf B Biointerfaces 167: 191-196

93. Terada D, Sotoma S, Harada Y, Igarashi R, Shirakawa M (2018) Onepot synthesis of highly dispersible fluorescent nanodiamonds for bioconjugation. Bioconjug Chem 29: 2786-2792

94. Laube C, Oeckinghaus T, Lehnert J, Griebel J, Knolle W, Denisenko A, Kahnt A, Meijer J, Wrachtrup J, Abel B (2019) Controlling the fluorescence properties of nitrogen vacancy centers in nanodiamonds. Nanoscale 11: 1770-1783

95. Reineck P, Cepelli M, Lau DWM, Jeske J, Field MR, Ohshima T, Greentree AD, Gibson BC (2017) Bright and photostable nitrogen-vacancy fluorescence from unprocessed detonation nanodiamond. Nanoscale 9: 497-502

96. Kim H, Kim H, Lee J, Lim WC, Eliades JA, Kim J, Song J, Suk J (2018) Fabrication of silicon-vacancy color centers in nanodiamonds by using Si-ion implantation. J Korean Phys Soc 73: 661 https://doi. org/10.3938/jkps.73.661

97. Magyar A, Hu W, Shanley T, Flatte ME, Hu E, Aharonovich I (2014) Synthesis of luminescent europium defects in diamond. Nat Commun 5: 3523 https:/ / doi.org/10.1038/ncomms4523

98. Lin Y, Su D (2014) Fabrication of nitrogen-modified annealed nanodiamond with improved catalytic activity. ACS Nano 8: 7823-7833

99. Sekiguchi T, Sotoma S, Harada Y (2018) Fluorescent nanodiamonds as a robust temperature sensor inside a single cell. Biophys Physicobiol 15: 229-234

100. Alkahtani MH, Alghannam F, Jiang L, Rampersaud AAAA, Brick R, Gomes CL, Scully MO, Hemmer (2018) Fluorescent nanodiamonds: past, present and future. Nanophotonics 7: 1423-1453

101. Tzeng JK, Faklaris O, Chang BM, Kuo Y, Hsu JH, Chang HC (2011) Superresolution imaging of albumin-conjugated fluorescent nanodiamonds in cells by stimulated emission depletion. Angew Chem Int Ed Engl 50: 2262-2265

102. Hell SW (2015) Nanoscopy with focus light (Nobel lecture). Angew Chem Int Ed Engl 54: 8054-8066
103. Gruber A, Dräbenstedt A, Tietz C, Fleury L, Wrachtrup J, von Borczyskowski (1997) Scanning confocal optical microscopy and magnetic resonance on single defect centers. Science 276: 20122014

104. Hegyi A, Yablonovitch E (2013) Molecular imaging by optically detected electron spin resonance of nitrogen-vacancies in nanodiamonds. Nano Lett 13: 1173-1178

105. Gao Y, Yu Y, Sanchez L, Yu Y (2017) Seeing the unseen: Imaging rotation in cells with designer anisotropic particles. Micron 101: 123-131

106. Sadzak N, Heritier M, Benson O (2018) Coupling a single nitrogen-vacancy center in nanodiamond to superparamagnetic nanoparticles. Sci Rep 8: 8430 https://doi.org/10.1038/s41598018-26633-9

107. Dulińska-Litewka J, Łazarczyk A, Hałubiec P, Szafrański O, Karnas K, Karewicz A (2019) Superparamagnetic iron oxide nanoparticles-current and prospective medical applications. Materials 12: 617 https://doi.org/10.3390/ma12040617

108. Perevedentseva E, Karmenyan A, Lin YC, Song CY, Lin ZR, Ahmed AI, Chang CC, Norina SB, Bessalova V, Perov N, Levinson O, Zousman B, Cheng CL (2018) Multifunctional biomedical applications of magnetic nanodiamond. J Biomed Opt 23: 091404 https://doi org/10.1117/1.JBO.23.9.091404

109. Weng MF, Chiang SY, Wang NS, Niu H (2009) Fluorescent nanodiamonds for specifically targeted bioimaging: application to the interaction of transferrin with transferrin receptor. Diam Relat Mater 18: 587-591

110. Fang CY, Vaijayanthimala V, Cheng CA, Yeh SH, Chang CF, Li CL, Chang HC (2011) The exocytosis of fluorescent nanodiamond and its use as a long-term cell tracker. Small 7(23): 3363-3370

111. Lien ZY, Hsu TC, Liu KK, Liao WS, Hwang KC, Chao JI (2012) Cancer cell labeling and tracking using fluorescent and magnetic nanodiamond. Biomaterials 33: 6172-6185

112. Mkandawire M, Pohl A, Gubarevich T, Lapina V, Appelhans D, Rödel G, Pompe W, Schreiber J, Opitz J (2009) Selective targeting of green fluorescent nanodiamond conjugates to mitochondria in HeLa cells. J Biophotonics 2: 596-606

113. Lin HH, Lee HW, Lin RJ, Huang CW, Liao YC, Chen YT, Fang JM, Lee TC, Yu AL, Chang HC (2015) Tracking and finding slow-proliferating/quiescent cencer stem cells with fluorescent nanodiamonds. Small 11: 4394-4402

114. Wu TJ, Tzeng YK, Chang WW, Cheng CA, Kuo Y, Chien CH, Chang HC, Yu J (2013) Tracking the engraftment and regenerative capabilities of transplanted lung stem cells using fluorescent nanodiamonds. Nat Nanotechnol 8: 682-689

115. Li Y, Tong Y, Cao R, Tian Z, Yang B, Yang P (2014) In vivo enhancement of anticancer therapy using bare or chemotherapeutic drug-bearing nanodiamond particles. Int J Nanomedicine 9: 1065-1082

116. Li L, Tian L, Zhao W, Li Y, Yang B (2016) Acetate ions enhance load and stability of doxorubicin onto PEGylated nanodiamond for selective tumor intracellular controlled release and therapy. Integr Biol (Camb) 8: 956-967

117. Khalid A, Mitropoulos AN, Marelli B, Tomljenovic-Hanic S, Omenetto FG (2016) Doxorubicin loaded nanodiamond-silk spheres for fluorescence tracking and controlled drug release. Biomed Opt Express 7: 132-147

118. Guan B, Zou F, Zhi J (2010) Nanodiamond as the $\mathrm{pH}$-responsive vehicle for an anticancer drug. Small 6: 1514-1519

119. Khalid A, Mitropoulos AN, Marelli B, Simpson DA, Tran PA, Omenetto FG, Tomljenovic-Hanic S (2015) Fluorescent nanodiamond silk fibroin spheres: advanced nanoscale bioimaging tool. ACS Biomater Sci Eng 1: 1104-1113

120. Prieto-Vila M, Takahashi R, Usuba W, Kohama I, Ochiya T (2017) Drug resistance driven by cancer stem cells and their niche. Int J Mol Sci 18: 2574 https://doi.org/10.3390/ijms18122574

121. Toh TB, Lee DK, Hou W, Abdullah LN, Nguyen J, Ho D, Chow EKH (2014) Nanodiamond-mitoxantrone complexes enhance drug retention in chemoresistant breast cancer cells. Mol Pharm 11: 2683-2691 
122. Chow EK, Zhang XQ, Chen M, Lam R, Robinson E, Huang H, Schaffer D, Osawa E, Goga A, Ho D (2011) Nanodiamond therapeutic delivery agents mediate enhanced chemoresistant tumor treatment. Sci Transl Med 3: 73ra21 https:/ / doi.org/10.1126/scitranslmed.3001713

123. Xi G, Robinson E, Mania-Farnell B, Vanin EF, Shim KW, Takao T, Allender EV, Mayanil CS, Soares MB, Ho D, Tomita T (2014) Convection-enhanced delivery of nanodiamond drug delivery platforms for intracranial tumor treatment. Nanomedicine 10: 381-391

124. Wang X, Low XC, Hou W, Abdullah LN, Toh TB, Rashid MMA, Ho D, Chow EKH (2014) Epirubicin-adsorbed nanodiamonds kill chemoresistant hepatic cancer stem cells. ACS Nano 8: 12151-12166

125. Lim DG, Jung JH, Ko HW, Kang E, Jeong SH (2016) Paclitaxel-nanodiamond nanocomplexes enhance aqueous dispersibility and drug retention in cells. ACS Appl Mater Interfaces 8: 23558-23567

126. Hsieh YH, Liu KK, Sulake RS, Chao JI, Chen C (2015) Microwave-assisted efficient conjugation of nanodiamond and paclitaxel. Bioorg Med Chem Lett 25: 2074-2077

127. Xu S, Cui F, Huang D, Zhang D, Zhu A, Sun X, Cao Y, Ding S, Wang Y, Gao E, Zhang F (2019) PD-L1 monoclonal antibody-conjugated nanoparticles enhance drug delivery level and chemotherapy efficacy in gastric cancer cells. Int J Nanomedicine 14: 17-32

128. Li D, Chen X, Wang H, Liu J, Zheng M, Fu Y, Yu Y, Zhi J (2017) Cetuximab-conjugated nanodiamonds drug delivery system for enhanced targeting therapy and 3D Raman imaging. J Biophotonics 10: 1636-1646

129. Lin YW, Raj EN, Liao WS, Lin J, Liu KK, Chen TH, Cheng HC, Wang CC, Li LY, Chen C, Chao JI (2017) Co-delivery of paclitaxel and cetuximab by nanodiamond enhances mitotic catastrophe and tumor inhibition. Sci Rep 7: 9814 https:/ / doi.org/10.1038/s41598-017-099838

130. Dziawer Ł, Majkowska-Pilip A, Gaweł D, Godlewska M, Pruszyński M, Jastrzębski J, Wąs B, Bilewicz A (2019) Trastuzumab-modified gold nanoparticles labeled with ${ }^{211} \mathrm{At}$ as a prospective tool for local treatment of HER2-positive breast cancer. Nanomaterials (Basel) 9: 632 https:// doi.org/10.3390/nano9040632

131. Torelli MD, Rickard AG, Backer MV, Filonov DS, Nunn NA, Kinev AV, Backer JM, Palmer GM, Shenderova OA (2019) Targeting fluorescent nanodiamonds to vascular endothelial growth factor receptors in tumor. Bioconjugate Chem 30: 604-613

132. Zhang JL, Gong LQ, Yan Q, Zhou NN, Lee VHF, Guan XY (2019) Advances in surface markers of liver cancer stem cell. Hepatoma Res 5: 27 https://doi.org/10.20517/2394-5079.2019.13

133. Seca AML, Pinto DCGA (2018) Plant secondary metabolites as anticancer agents: successes in clinical trials and therapeutic application. Int J Mol Sci 19: pii: E263 https:/ / doi.org/10.3390/ijms19010263

134. Gismondi A, Reina G, Orlanducci S, Mizzoni F, Gay S, Terranova ML, Canini A (2015) Nanodiamonds coupled with plant bioactive metabolites: A nanotech approach for cancer therapy. Biomaterials 38: $22-35$

135. Gupta C, Prakash D, Gupta S (2017) Cancer treatment with nano-diamonds. Front Biosci (Schol Ed) 1: 62-70

136. Ostadhossein F, Mahmoudi N, Morales-Cid G, Tamjid E, Navas-Martos FJ, Soriano-Cuadrado B, Paniza JML, Simchi A (2015) Development of chitosan/bacterial cellulose composite films containing nanodiamonds as a potential flexible platform for wound dressing. Materials (Basel) 8: 6401-6418

137. Chen M, Pierstorff ED, Lam R, Li SY, Huang H, Osawa E, Ho D (2009) Nanodiamond-mediated delivery of water-insoluble therapeutics. ACS Nano 3: 2016-2022

138. Rouhani P, Govindaraju N, Iyer JK, Kaul R, Kaul A, Singh RN (2016) Purification and functionalization of nanodiamond to serve as a platform for amoxicillin delivery. Mater Sci Eng C Mater Biol Appl 63: 323-332

139. Beranova J, Seydlova G, Kozak H, Potocky S, Konopasek I, Kromka A (2012) Antibacterial behawior of diamond nanoparticles against Escherichia coli. Phys Status Solidi Basic 249: 2581-2584
140. Hristova K, Pecheva E, Pramatarova L, Altankov G (2011) Improved interaction of osteoblast-like cells with apatite-nanodiamond coatings depends on fibronectin. J Mater Sci Mater Med 22: 1891-1900

141. Edgington RJ, Thalhammer A, Welch JO, Bongrain A, Bergonzo P, Scorsone E, Jackman RB, Schoepfer R (2013) Patterned neuronal networks using nanodiamonds and the effect of varying nanodiamond properties on neuronal adhesion and outgrowth. J Neural Eng 10: 056022 https:/ / doi.org/10.1088/1741-2560/10/5/056022

142. Keremidarska M, Hikov T, Radeva E, Pramatarova L, Krasteva N (2014) Effect of nanodiamond modification of siloxane surfaces on stem cell behaviour. J Phys Conf Ser 558: 012056 https://doi. org/10.1088/1742-6596/558/1/012056

143. Taylor AC, Gonzalez CH, Miller BS, Edgington RJ, Ferretti P, Jackman RB (2017) Surface functionalisation of nanodiamonds for human neural stem cell adhesion and proliferation. Sci Rep 7: 7307 https://doi.org/10.1038/s41598-017-07361-y

144. Specht CG, Williams OA, Jackman RB, Schoepfer R (2004) Ordered growth of neurons on diamond. Biomaterials 25: 4073-4078

145. Chang WC, Sretavan DW (2008) Novel high-resolution micropatterning for neuron culture using polylysine adsorption on a cell repellant, plasma-polymerized background. Langmuir 24: 13048-13057

146. Kadlecova Z, Baldi L, Hacker D, Wurm FM, Klok HA (2012) Comparative study on the in vitro cytotoxicity of linear, dendritic, and hyperbranched polylysine analogues. Biomacromolecules 13: 31273137

147. Cellot G, Cilia E, Cipollone S, Rancic V, Sucapane A, Giordani S, Gambazzi L, Markram H, Grandolfo M, Scaini D, Gelain F, Casalis L, Prato M, Giugliano M, Ballerini L (2009) Carbon nanotubes might improve neuronal performance by favouring electrical shortcuts. Nat Nanotechnol 4: 126-133

148. Baldrighi M, Trusel M, Tonini R, Giordani S (2016) Carbon nanomaterials interfacing with neurons: an in vivo perspective. Front Neurosci 10: 250 https:/ / doi.org/10.3389/fnins.2016.00250

149. Hopper AP, Dugan JM, Gill AA, Fox OJL, May PW, Haycock JW, Claeyssens F (2014) Amine functionalized nanodiamond promotes cellular adhesion, proliferation and neurite outgrowth. Biomed Mater 9: 045009 https:/ / doi.org/10.1088/1748-6041/9/4/045009

150. Revell PA (2008) The combined role of wear particles, macrophages and lymphocytes in the loosening of total joint prostheses. J R Soc Interface 5: 1263-1278

151. Catledge SA, Thomas V, Vohra YK (2013) Nanostructured diamond coatings for orthopaedic applications. Woodhead Publ Ser Biomater 2013: 105-150

152. Chang JD (2014) Future bearing surfaces in total hip arthroplasty. Clin Orthop Surg 6: 110-116

153. Papo MJ, Catledge SA, Vohra YK, Machado C (2004) Mechanical wear behavior of nanocrystalline and multilayer diamond coatings on temporomandibular joint implants. J Mater Sci Mater Med 15: 773-777

154. Lee DK, Kee T, Liang Z, Hsiou D, Miya D, Wu B, Osawa E, Chow EKH, Sung EC, Kang MK, Ho D (2017) Clinical validation of a nanodiamond-embedded thermoplastic biomaterial. Proc Natl Acad Sci USA 114: E9445-E9454

155. Bejarano J, Navarro-Marquez M, Morales-Zavala F, Morales JO, Garcia-Carvajal I, Araya-Fuentes E, Flores Y, Verdejo HE, Castro PF, Lavandero S, Kogan MJ (2018) Nanoparticles for diagnosis and therapy of atherosclerosis and myocardial infarction: evolution toward prospective theranostic approaches. Theranostics 8: 4710-4732

156. Wang Z, Cai N, Zhao D, Xu J, Dai Q, Xue Y, Luo X, Yang Y, Yu F (2013) Mechanical reinforcement of electrospun water-soluble polymer nanofibers using nanodiamonds. Polymer Composites 34: 17351744

157. Brady MA, Renzing A, Douglas TE, Liu Q, Wille S, Parizek M, Bacakova L, Kromka A, Jarosova M, Godier G, Warnkel PH (2015) Development of composite poly(lactide-co-glycolide)- nanodiamond scaffolds for bone cell growth. J Nanosci Nanotechnol 15: 1060-1069 
158. Mochalin VN, Neitzel I, Etzold BJ, Peterson A, Palmese G, Gogotsi Y (2011) Covalent incorporation of aminated nanodiamond into an epoxy polymer network. ACS Nano 5: 7494-7502

159. Zhang Q, Mochalin VN, Neitzel I, Knoke IY, Han J, Klug CA, Zhou JG, Lelkes PI, Gogotsi Y (2011) Fluorescent PPLA-nanodiamond composites for bone tissue engineering. Biomaterials 32: 87-94

160. Zhang F, Song Q, Huang X, Li F, Wang K, Tang Y, Hou C, Shen H (2016) A novel high mechanical property PLGA composite matrix loaded with nanodiamond-phospholipid compound for bone tissue engineering. ACS Appl Mater Interfaces 8: 1087-1097

161. Suliman S, Xing Z, Wu X, Xue Y, Pedersen TO, Sun Y, Doskeland AP, Nickel J, Waag T, Lygre H, Finne-Wistrand A, Steinmüller-Nethl D, Krueger A, Mustafa K (2015) Release and bioactivity of bone mor- phogenetic protein- 2 are affected by scaffold binding techniques in vitro and in vivo. J Control Release 197: 148-157

162. Stigler RG, Schimke MM, Bigus S, Steinmüller-Nethl D, Tillmann K, Lepperdinger G (2019) Pervasion of beta-tricalcium phosphate with nanodiamonds particles yields efficient and safe bone replacement material amenable for biofunctionalization and application in large-size osseous defect healing. Nanomedicine 16: 250-257

163. Wu X, Bruschi M, Waag T, Schweeberg S, Tian Y, Meinhardt T, Stigler R, Larsson K, Funk M, Steinmüller-Nethl D, Rasse M, Krueger A (2017) Functionalization of bone implants with nanodiamond particles and angiopoietin-1 to improve vascularization and bone regeneration. J Mater Chem B 5: 6629-6636

\section{Nanodiamonds: unique nanoparticles for use in biomedicine and biotechnology}

\section{Patryk Nowicki ${ }^{\bowtie}$, Elżbieta Czarniewska}

Department of Animal Physiology and Development, Institute of Experimental Biology, Faculty of Biology, Adam Mickiewicz University in Poznań

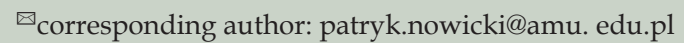

Key words: nanodiamonds, carriers, biologically active compounds, bioimaging, anti-cancer therapy, tissue engineering

Acknowledgements: This work was created during the realisation of the project number 2017/27/N/NZ9/00266 supported by the National Science Center

\section{ABSTRACT}

Nanodiamonds are ultra-fine diamond particles, which due to their nano-scale size, unique physico-chemical properties, and a large ratio of easily chemically modifiable surface to volume, are of interest to biologists, chemists and physicists. This work is a review of the literature on their preparation, properties and perspectives related to the possibility of their use in biomedical sciences. The high biocompatibility of nanodiamonds, confirmed by a number of in vivo and in vitro studies, distinguishes them from other nanoparticles and allows their use as a neutral system for transporting biologically active compounds. Such nanoparticles can be used as carriers of peptides, proteins, nucleic acids, drugs or other synthetic compounds that will cause the intended biological effect in the body, in bioimaging and tissue engineering. Promising results of studies on different biological models suggest practical applications of nanotechnological solutions based on nanodiamonds. 